\title{
Soil cultures - the adaptive cycle of agrarian soil use in Central Europe: an interdisciplinary study using soil scientific and archaeological research
}

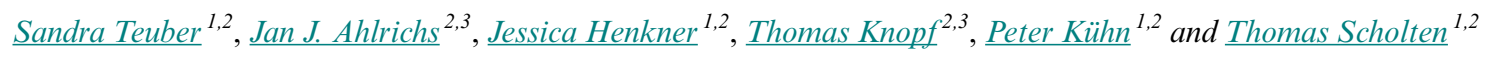

\begin{abstract}
Today's global challenges (e.g., food security) are not unprecedented in human history. Starting with the Neolithic transition, the agricultural sector and society underwent several cultural and technological changes and endured natural challenges. These challenges and changes are analyzed by using the adaptive cycle metaphor and the social-ecological system as tools to show the complexity of human-environment interactions and their development. The analysis relies on archaeological, pedological, and botanical research, and demonstrates the importance of interdisciplinary work. Agrarian soil use as a social-ecological system persisted in Central Europe for 7000 years and underwent an adaptive cycle from the Neolithic transition to industrialization. With agriculture's mechanization, a second adaptive cycle started. The resilience of agrarian soil use for thousands of years shows that agriculture, as a human-environmental interaction, is adaptive to change. Understanding past agricultural challenges and changes using archaeological and soil scientific data puts the present development into a new perspective. A cultural perspective on soils might trigger soil protection and sustainable land use in a technical as well as political domain. Applying social-ecological system and adaptive cycle concepts to this interdisciplinary reconstruction of agrarian soil use illustrates their usefulness for archaeology and soil science.
\end{abstract}

Key Words: archaeobotany; archaeology; adaptive cycle; agriculture; historical overview; social-ecological system; soil science

\section{INTRODUCTION}

Global climate change, degradation and erosion of soils, rising social inequality, and food insecurity comprise today's major human challenges (Tilman et al. 2002, Blum and Eswaran 2004, Luterbacher et al. 2004, Battisti and Naylor 2009, Lal 2010, Foley et al. 2011). Studies of past human-environment interactions show that these are not unprecedented in history (Costanza et al. 2007, Caseldine and Turney 2010, Büntgen et al. 2011). Agriculture, as a system based on human-environmental interaction, also has had an impact on societies and the environment in Central Europe since its origin and spread from the Near East around 9500 BCE (Evans 2012).

The development of the agricultural system is analyzed using the concepts of the adaptive cycle and the social-ecological system (Gunderson and Holling 2002). The adaptive cycle is repeatedly used in research; for example, in the bioenergy sector in Northern Germany (Grundmann et al. 2012) or in the resilience of two contrasting social-ecological systems (Carpenter et al. 2001). Dorren and Imeson (2005) used it to develop a framework on soil erosion for Southern Limburg. Beier et al. (2009) investigated forest management in Alaska, and Allison and Hobbs (2004) expanded the use of the adaptive cycle to economics in their analysis of the Western Australian Agricultural Region. Zimmermann (2012) used a specification of the adaptive cycle to improve the understanding of mobility structures in prehistoric Europe. These examples show dynamic social-ecological systems, and demonstrate that the adaptive cycle is a useful tool for investigating the development of such systems.

In the following, agrarian soil use as a social-ecological system is introduced and analyzed using the adaptive cycle metaphor. Due to limited written sources for (pre)historic times, the analysis focuses on archaeological, pedological, palynological, and historical records that have been published by scientists of the respective disciplines. The aim is to investigate changes in agrarian soil use that are observable for the variables soil, crop, and technology. Is the adaptive cycle useful for explaining changes over several thousand years? What major changes led to a restructuring of the social-ecological system? Are the developments in the Neolithic comparable to industrialization? If so, are there implications for soil use in the future?

\section{AGRARIAN SOIL USE AS A SOCIAL-ECOLOGICAL SYSTEM}

A social-ecological system (SES) is characterized by the integration of natural and social components (Berkes and Folke 1998, Berkes et al. 2003, Berkes 2004). Social-ecological systems shape the world, and to understand them, it is necessary to split the bigger systems into smaller parts. However, the smaller systems remain part of other SESs. Our analysis focuses on agrarian soil use as an SES, which is part of a bigger SES, and in turn can be divided into smaller SESs on any temporal or spatial scale. The adaptive cycle metaphor (Gunderson and Holling 2002) is used as a theoretical framework for the narrative of agricultural history in Central Europe.

The main variable of the SES agrarian soil use is soil, which has been used agriculturally since the Neolithic transition. This use, or more precisely deforestation, has led to changes in the landscape and soil through erosion and accumulation processes. Under forests, the natural vegetation in Central Europe, erosion is minor because the roots of the vegetation stabilize the soil, preventing its erosion, and the canopy slows the rainfall (Pimentel and Kounang 1998, Geißler et al. 2012). Thus, the erosion and accumulation of soil material is connected to changes in vegetation cover. Prior to the Neolithic transition, this was related to climate events (Dreibrodt et al. 2010a). After the Neolithic

${ }^{1}$ Eberhard Karls University Tübingen, Faculty of Geoscience, Research Area Geography, Chair of Soil Science and Geomorphology, ${ }^{2}$ Eberhard Karls University Tübingen, SFB 1070 RESOURCECULTURES, ${ }^{3}$ Eberhard Karls University Tübingen, Faculty of Philosophy, Institute of Pre- and Protohistory and Medieval Archaeology 
Table 1. Several archaeobotanical studies that investigated the crops used in Central Europe in (pre-) historic times. The crops are named according to the study cited.

\begin{tabular}{|c|c|c|c|c|}
\hline Author & Period & Region & Analysis & Crops identified in analysis \\
\hline $\begin{array}{l}\text { Bogaard et al. } \\
\text { (2013) }\end{array}$ & Neolithic & $\begin{array}{l}\text { Europe (examples } \\
\text { in this table from } \\
\text { Central Europe) }\end{array}$ & $\begin{array}{l}\text { Whole grains from the } \\
\text { same stratigraphic unit }\end{array}$ & $\begin{array}{l}\text { Einkorn (Triticum monococcum), emmer (T. dicoccum), free-threshing } \\
\text { wheat, naked barley (Hordeum vulgare), lentil (Lens culinaris), pea } \\
\text { (Pisum) }\end{array}$ \\
\hline $\begin{array}{l}\text { Kirleis et al. } \\
(2012)\end{array}$ & Neolithic & Northern Germany & Charred plant remains & $\begin{array}{l}\text { (Naked) barley }(H . \text { vulgare }), \text { emmer }(T \text {. dicoccum }), \text { einkorn }(T . \\
\text { monococcum }), \text { naked wheat }(T . \text { aestivum })\end{array}$ \\
\hline $\begin{array}{l}\text { Bogaard et al. } \\
(2011)\end{array}$ & Neolithic & $\begin{array}{l}\text { Vaihingen, Enz, } \\
\text { Germany }\end{array}$ & Chaff (glume base) & $\begin{array}{l}\text { Einkorn (T. monococcum), emmer ( } T \text {. dicoccum), "new type", opium } \\
\text { poppy (Papaver somniferum), feathergrass (Stipa) }\end{array}$ \\
\hline Herbig (2009) & Neolithic & $\begin{array}{l}\text { Lake Constance/ } \\
\text { Upper Swabia, } \\
\text { southwest Germany }\end{array}$ & $\begin{array}{l}\text { Archaeobotanical } \\
\text { (profile columns, surface } \\
\text { samples) }\end{array}$ & $\begin{array}{l}\text { Emmer (T. dicoccon Schrank), einkorn (T. monococcum L.), tetraploid } \\
\text { naked wheat (T. durum Desf./turgidum } \mathrm{L} .) \text {, naked barley }(\text { H. vulgare } \\
\text { ssp. nudum), opium poppy (Papaver somniferum L.), flax (Linum } \\
\text { usitatissimum L.), single finds of pea (Pisum sativum } \text { L.), lentil (Lens } \\
\text { culinaris } \text { L.) }\end{array}$ \\
\hline $\begin{array}{l}\text { Rösch }(1987, \\
1993)\end{array}$ & $\begin{array}{l}\text { Neolithic to } \\
\text { Bronze Age }\end{array}$ & $\begin{array}{l}\text { Lake Constance, } \\
\text { southwest Germany }\end{array}$ & Pollen analysis & $\begin{array}{l}\text { Naked wheat (T. aestivum/durum), barley }(H \text {. vulgare } \mathrm{L} .) \text {, emmer }(T \text {. } \\
\text { dicoccum }) \text {, einkorn }(T \text {. monococcum } \mathrm{L} \text {.), flax (Linum usitatissimum } \mathrm{L} .) \text {, } \\
\text { opium poppy (Papaver somniferum } \mathrm{L} \text {.), spelt (T. spelta), millet } \\
\text { (Panicum miliaceum), pulses }\end{array}$ \\
\hline Rösch (1996) & $\begin{array}{l}\text { Late } \\
\text { Neolithic to } \\
\text { Bronze Age }\end{array}$ & $\begin{array}{l}\text { Southwest } \\
\text { Germany }\end{array}$ & $\begin{array}{l}\text { Pollen analysis, charred } \\
\text { plant macroremains }\end{array}$ & $\begin{array}{l}\text { Einkorn ( } T \text {. monococcum), emmer ( } T \text {. dicoccum), naked wheat ( } T \text {. } \\
\text { turgidum s.l.), barley (H. vulgare), spelt (T. spelta), millet (Panicum } \\
\text { miliaceum) }\end{array}$ \\
\hline $\begin{array}{l}\text { Kanstrup et al. } \\
\text { (2014) }\end{array}$ & $\begin{array}{l}\text { Neolithic to } \\
\text { Iron Age }\end{array}$ & Denmark & $\begin{array}{l}\text { Charred } \\
\text { archaeobotanical cereal } \\
\text { remains, isotope analysis }\end{array}$ & $\begin{array}{l}\text { Emmer (T. dicoccum), spelt ( } T \text {. spelta), naked barley (H. vulgare, var. } \\
\text { Nudum) }\end{array}$ \\
\hline Hubbard (1980) & $\begin{array}{l}\text { Neolithic to } \\
\text { Medieval } \\
\text { period }\end{array}$ & Europe & $\begin{array}{l}\text { Analysis of charred } \\
\text { remains and pottery } \\
\text { imprints }\end{array}$ & $\begin{array}{l}\text { Barley ( } H \text {. vulgare), emmer ( } T \text {. dicoccum \& dicoccoides), einkorn }(T . \\
\text { monococcum \& bocoticum), millet (Panicum miliaceum), oat (Avena } \\
\text { sativa \& strigosa), wheat (T. aestivum } \text { s.1.), rye (Secale cereale) }\end{array}$ \\
\hline $\begin{array}{l}\text { Mäckel et al. } \\
(2003)\end{array}$ & $\begin{array}{l}\text { Neolithic to } \\
\text { Medieval } \\
\text { period }\end{array}$ & $\begin{array}{l}\text { Upper Rhine } \\
\text { Lowlands, southern } \\
\text { Black Forest, } \\
\text { southwest Germany }\end{array}$ & $\begin{array}{l}\text { Pollen analysis, } \\
\text { evaluation of fossil soils }\end{array}$ & $4000 \mathrm{BC}$ : cerealia \\
\hline Hjelle et al. (2012) & $\begin{array}{l}\text { Neolithic to } \\
\text { Medieval } \\
\text { period }\end{array}$ & Norway & $\begin{array}{l}\text { Pollen analysis, charred } \\
\text { grains }\end{array}$ & $\begin{array}{l}\text { Charred grains of } H \text {. vulgare (present from Late Neolithic to Early } \\
\text { Bronze Age), cerealia pollen, mainly Hordeum type, but also Avena and } \\
\text { Triticum type (Early Iron Age) }\end{array}$ \\
\hline Behre (1992) & $\begin{array}{l}\text { Neolithic to } \\
\text { Medieval } \\
\text { period }\end{array}$ & Central Europe & $\begin{array}{l}\text { Carbonized grains, } \\
\text { pollen diagram }\end{array}$ & $\begin{array}{l}\text { Rye (Secale cereale) rare in Neolithic, increasing during pre-Roman } \\
\text { Iron Age and Roman period and great increase in the Middle Ages }\end{array}$ \\
\hline $\begin{array}{l}\text { Wieckowska et al. } \\
\text { (2012) }\end{array}$ & $\begin{array}{l}\text { Neolithic to } \\
\text { modern times }\end{array}$ & $\begin{array}{l}\text { Großer Eutiner See, } \\
\text { northern Germany }\end{array}$ & Pollen analysis & $\begin{array}{l}\text { Triticum- and Averna-type pollen, Secale (Iron Age onward), Hordeum } \\
\text { (Iron Age onward) }\end{array}$ \\
\hline $\begin{array}{l}\text { Dreßler et al. } \\
(2006)\end{array}$ & $\begin{array}{l}\text { Neolithic to } \\
\text { modern times }\end{array}$ & $\begin{array}{l}\text { Lake } \\
\text { Dudinghausen, } \\
\text { northern Germany }\end{array}$ & Pollen analysis & $\begin{array}{l}\text { Hordeum, Triticum, Secale (Medieval period onward) --> cereal pollen } \\
\text { increased in Modern times }\end{array}$ \\
\hline Rösch (1998) & $\begin{array}{l}\text { Neolithic to } \\
\text { modern times }\end{array}$ & $\begin{array}{l}\text { Southwest } \\
\text { Germany }\end{array}$ & Review & $\begin{array}{l}\text { T. dicoccum, T. monococcum, H. vulgare, T. aestivum/durum, T. spelta } \\
\text { (minor in Neolithic but increase in Bronze Age), Secale cereale (minor } \\
\text { in Neolithic but increase in Bronze Age), Panicum miliaceum (from } \\
\text { Bronze Age on), Setaria italica (from Bronze Age on), Avena (from } \\
\text { Bronze Age on), Oryza sativa (from Late Medieval period on), Zea } \\
\text { mays (from modern times on), Linum usitatissimum, Papaver } \\
\text { somniferum, Brassica rapa, Camelina sativa, Cannabis sativa (minor } \\
\text { from Iron Age on), Pisum sativum, Lens culinaris, Vicia ervilia (few in } \\
\text { Neolithic and in Iron Age), V. faba (from Bronze Age on), V. sativa } \\
\text { (few in Roman and High Medieval times) }\end{array}$ \\
\hline $\begin{array}{l}\text { Rösch and } \\
\text { Tserendorj (2011) }\end{array}$ & Bronze Age & $\begin{array}{l}\text { Huzenbacher See, } \\
\text { southwest Germany }\end{array}$ & Pollen analysis & Cerealia, secale (Medieval period) \\
\hline $\begin{array}{l}\text { Gauthier and } \\
\text { Richard (2009) }\end{array}$ & Bronze Age & $\begin{array}{l}\text { Lake Bourget, } \\
\text { France }\end{array}$ & Pollen analysis & Cerealia \\
\hline $\begin{array}{l}\text { Stika and Heiss } \\
(2013)\end{array}$ & Bronze Age & Europe & Review & Barley, emmer, einkorn, spelt, free-threshing wheat, millet, oat, rye \\
\hline $\begin{array}{l}\text { Dreslerova et al. } \\
(2013)\end{array}$ & $\begin{array}{l}\text { Bronze Age } \\
\text { to Early Iron } \\
\text { Age }\end{array}$ & Czech Republic & $\begin{array}{l}\text { Charred plant } \\
\text { macroremains }\end{array}$ & $\begin{array}{l}\text { Emmer ( } T \text {. dicoccum Schübl.), barley ( } H \text {. vulgare } \mathrm{L} .) \text {, millet (Panicum } \\
\text { miliaceum } \mathrm{L} .) \text {, spelt }(T \text {. spelta } \mathrm{L} \text {.), later also naked wheat ( } T \text {. aestivum } \\
\text { L./compactum Host./durum } \text { Desf./turgidum } \mathrm{L} .) \text {, very low numbers of } \\
\text { oat (Avena sativa } \mathrm{L} .) \text { and rye (Secale cereale } \mathrm{L} .)\end{array}$ \\
\hline
\end{tabular}




\begin{tabular}{|c|c|c|c|}
\hline $\begin{array}{l}\text { Kerig and } \\
\text { Lechterbeck } \\
\text { (2004) }\end{array}$ & $\begin{array}{l}\text { Bronze Age } \\
\text { to Medieval } \\
\text { period }\end{array}$ & $\begin{array}{l}\text { Lake Steisslingen, } \\
\text { southwest Germany }\end{array}$ & Pollen analysis \\
\hline Rösch et al. (1992) & $\begin{array}{l}\text { Roman to } \\
\text { post- } \\
\text { Medieval } \\
\text { period }\end{array}$ & $\begin{array}{l}\text { Southwest } \\
\text { Germany, northern } \\
\text { Switzerland }\end{array}$ & Review \\
\hline
\end{tabular}

\begin{tabular}{|c|c|c|c|}
\hline $\begin{array}{l}\text { Rebourg et al. } \\
\text { (2003) }\end{array}$ & $1493 / 1539$ & $\begin{array}{l}\text { Southern Spain/ } \\
\text { Germany }\end{array}$ & $\begin{array}{l}\text { Literature review } \\
\text { genetic markers }\end{array}$ \\
\hline $\begin{array}{l}\text { Hawkes and } \\
\text { Francisco-Ortega } \\
\text { (1993) }\end{array}$ & $1567 / 1574$ & $\begin{array}{l}\text { Gran Canaria/ } \\
\text { Tenerife }\end{array}$ & Literature review \\
\hline Cassman (1999) & 1967-1997 & Global & Harvested area \\
\hline
\end{tabular}

transition, land use change induced by humans led to erosion and the development of so-called colluvial deposits on foot slopes (Lang 2003, Leopold and Völkel 2007). The original reason for deforestation (e.g., clearance for fields or overgrazing) is difficult to determine; however, the analysis of colluvial deposits with ${ }^{14} \mathrm{C}$ dating and luminescence dating, and archaeobotanical and soil scientific research methods gives insight into the past (Eckmeier et al. 2007, Kadereit et al. 2010, Bogaard et al. 2013, Bakels 2014, Pietsch and Kühn 2014, Henkner et al. 2017). In international literature, the term "colluvial deposit" is unclearly connected to land use. Hereafter, the term "anthropogenic colluvial deposit" will be used when referring to soils, which studies suggest were formed due to land use change and agriculture.

Other variables of the SES agrarian soil use are climate and crops. Changes in crop plants are observable via archaeobotanical analyses (Rösch 1996). Crop refers to cereals (e.g., barley, wheat, rye), and excludes fruit, vegetables, and nuts. Climate change can be traced in ice cores, lake and ocean sediments, corals, tree rings, fossil leaves, and changes in pollen communities (Caseldine and Turney 2010, Aranbarri et al. 2014). The effect of climate on the settlement pattern of a region is discussed by experts (Berglund 2003, Zolitschka et al. 2003). While it is likely that climate change had an impact on agricultural practices, the extent is not clearly visible in the archives available for prehistoric times. Even with written sources, these refer to weather events and not climate per se. Therefore, climate effects on the SES agrarian soil use are not considered here.

The observable variable concerning society is the technological development of tools. The variable knowledge is difficult to define for times when no written sources exist. It is assumed here that technological development is accompanied by increasing knowledge. Knowledge/technology are used as one variable, which is traceable in archaeological finds. Thus, this study focuses only on observable variables that can be appropriately analyzed in the SES agrarian soil use, specifically soil, crops, and technology.
Triticum, Hordeum, Cerealia, rye (Iron Age)

Roman Period (1st-3rd century AD): Panicum miliaceum, T. spelta, Secale cereale, $H$. vulgare, T. aestivum, T. monococcum; in native Germania T. monococcum, H. vulgare, and Secale cereale

Late Roman period (3rd-5th century AD): one site investigated on upper Danube with H. vulgare, T. speta, and Avena sp.; T. aestivum, T. monococcum, and Secale cereale $(<10 \%)$

Merovingian period (6th/7th century AD): Avena sp., H. vulgare, T. spelta, T. aestivum, T. monococcum, Secale cereale Carolingian-Ottonian period (8th-10th century AD): T. aestivum, T. spelta, Avena sp., T. monococcum, $H$. vulgare, and Secale cereale High Medieval period (11th-13th century AD): Secale cereale, $T$. spelta, T. monococcum, Avena sp., H. vulgare, Panicum miliaceum, $T$. aestivum

Early modern period (16th-19th century AD): Panicum miliaceum, Avena sp., H. vulgare, T. aestivum, Secale cereale, T. spelta

Maize (Zea mays ssp. mays): several introductions

Potato (Solanum tuberosum/Ipomoea batatas)

Wheat (T. aestivum L.), rice (Oryza sativa L.), maize (Z. mays L.)

\section{THE ADAPTIVE CYCLE OF THE SOCIAL-ECOLOGICAL SYSTEM AGRARIAN SOIL USE}

The adaptive cycle was developed to explain ecosystem dynamics. It is composed of four phases: the r-phase of exploitation, the Kphase of conservation, the $\Omega$-phase of release or creative destruction, and the $\alpha$-phase of reorganization (Holling et al. 2002a, Holling and Gunderson 2002). This cycle is shaped by three properties: the potential of a system for change, the degree of connectedness between internal variables and processes, and the adaptive capacity of a system, its resilience as a measure of its vulnerability to unexpected shocks (Holling 2001). Holling and Gunderson (2002) state that the $\alpha$-phase starts a process of reorganization during which potential and resilience are high but connectedness is low. During the r-phase, resilience remains high and connectedness is low. In the K-phase, connectedness increases while resilience decreases. The system becomes more vulnerable to disturbance. Due to this vulnerability, a disturbance can cause creative destruction in the $\Omega$-phase in which potential is low. The sudden shift from the $\Omega$ - to $\alpha$-phase leads to a new cycle with loose connections, high resilience, and an increasing potential. In this phase, different recombinations are possible, which makes the outcome of the reorganization unpredictable (Holling and Gunderson 2002).

The adaptive cycle shows that systems are dynamic. The SES agrarian soil use developed over time, and while some processes led, for example, to a deterioration of soil properties, overall development enabled the SES to grow and diversify. With the help of the adaptive cycle narrative, the emergence of our present-day agricultural system is analyzed. Changes of the variables or within the variables of the SES affect the adaptive cycle, shape the SES, and determine its resilience or vulnerability to unpredictable shocks (Holling 2001).

The variables analyzed are soil, crops, and knowledge/technology. Soil formation is a slow and complex process (Stockmann et al. 2014); therefore, soil is a slowly changing variable. However, erosion events can be fast and lead to abrupt changes in the 
Fig. 1. The adaptive cycles of agrarian soil use in time (modified from Holling [2001] and Gronenborn et al. [2014]).
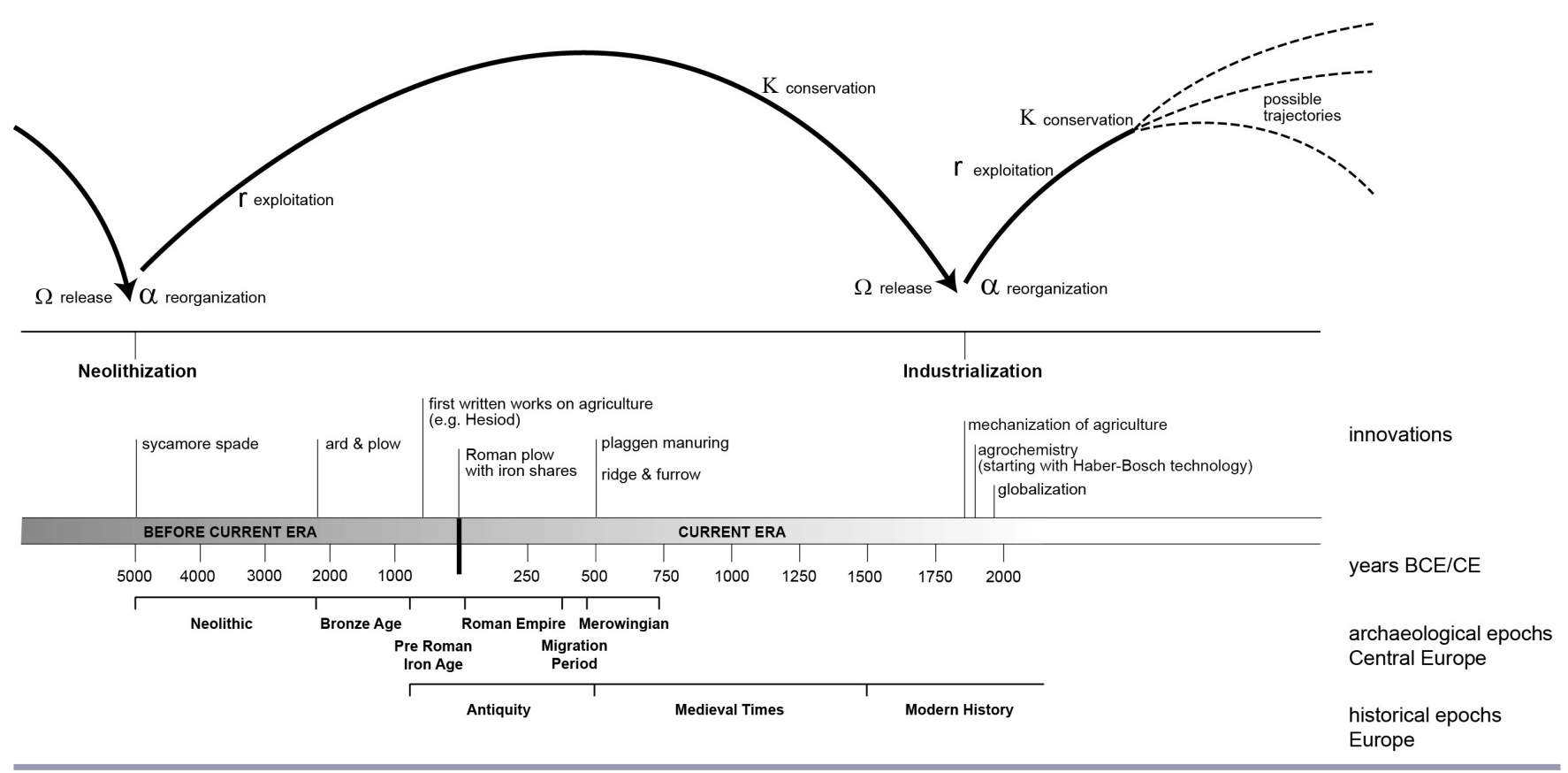

variable concerning its further use (Auerswald et al. 2009). The anthropogenic colluvial deposits are used as archives of land use. The slowly changing variable crop affects the SES through the introduction of new crops, which is visible in archaeobotanical records (Table 1, organized chronologically from Neolithic to modern times). The variable knowledge/technology influences the SES through fast changes that are implemented by humans, and are traceable in the archaeological record.

Societal changes, environmental factors, or a combination of both can lead to disturbances of the SES, which result in a reorganization of the system. After the disturbance and release, the system is reorganized, and a new phase of exploitation starts.

The SES agrarian soil use underwent one adaptive cycle from the Neolithic transition to the Industrial Revolution (Fig. 1). Through the use of soil, and the introduction of crops and new agrarian tools during the Neolithic transition, people settled down and produced higher food quantities (Childe 1936, Holling et al. 2002b). The Industrial Revolution marks the beginning of a second adaptive cycle with the industrialization of agriculture and food production, which simultaneously changed society by increasing the workforce of the secondary and tertiary sector. In between those two r-phases, most of society practiced agriculture (Evans 2012). The main crops of Central Europe remained similar to the ones introduced during the Neolithic, with the exception of potato or maize, which were introduced after the "discovery" of the American continent during the K-phase (Hawkes and Francisco-Ortega 1993, Rösch 1998, Rebourg et al. 2003). Soil cultivation depended on human and animal labor. The technology improved from the spade to the ard to the plow during the r-phase. While there was a succession of agricultural improvements, this development is similar to the $\mathrm{r}$ - and $\mathrm{K}$-specialists that settle in a new habitat, as described by Holling and Gunderson (2002).
Furthermore, Fath et al. (2015) state that in social systems, many small-scale adaptive cycles occur during the $\mathrm{r}$ - and $\mathrm{K}$-phase of a bigger adaptive cycle, resulting in a prolonged K-phase of continued development and influencing the interplay between fast-changing and slowly changing variables. Fath et al. (2015) introduced a refined concept, consisting of the r-, $\mathrm{K}_{-}, \mathrm{K}_{\mathrm{lim}}{ }^{-}, \Omega-$, and $\alpha$-stage, and applied that to business management. The r-stage has innovations and provides the possibility of testing the innovations, and the spirit is entrepreneurial. In the K-stage, knowledge on best practices exists, and the previously established standards are accepted. In the added $\mathrm{K}_{\mathrm{lim}}$-stage, crisis plans come into action, which need technologies and cooperation to implement them. In the $\Omega$-stage, improvisation is important, and access to a minimum of resources is required, while new actors and new knowledge need to be accepted. In the subsequent $\alpha$ stage, experimenting and development of prototypes is a key competence, which requires certain resources and a willingness to try new paths (Fath et al. 2015). If this is applied to the adaptive cycles of agrarian soil use, it can be shown that the r-phase of the first and the second adaptive cycle of agrarian soil use indeed was shaped by innovations and entrepreneurial or experimental spirit. In the following $\mathrm{K}$-phases, the previously introduced innovations are accepted, and best practice methods develop; e.g., the development and continuous use of the plow throughout the millennia. The $\mathrm{K}_{\text {lim }}$-stage could be represented by the development of motorized agrarian tools during industrialization to facilitate work and free the workforce for the growing industry. In the $\Omega$-stage, the new machines were accepted, and in the $\alpha$ stage, experimenting with the new technology occurred and new pathways of agrarian soil use were explored. Further, the development of new tools during the first adaptive cycle was accompanied by smaller adaptive cycles within the social system, which in turn prolonged the K-phase of the big adaptive cycle 
agrarian soil use. In the sections that follow, the terminology of Holling and Gunderson (2002) is used, excluding the $\mathrm{K}_{\mathrm{lim}}$-stage of Fath et al. (2015). However, there are references to the latter.

\section{ANALYSIS OF THE SOCIAL-ECOLOGICAL SYSTEM AGRARIAN SOIL USE IN CENTRAL EUROPE}

Beginning approximately 40,000-45,000 years ago, the anatomically modern humans replaced the Neanderthals in Europe (Mellars 2004, Pinhasi et al. 2012, Hublin 2015). When the ice shields retreated after the Late Glacial Maximum (Hughes and Gibbard 2015), a new $\alpha$-phase of the ecological system started with plant species and fauna spreading into the now ice-free space (Holling and Gunderson 2002), where soil formation processes started (Terberger et al. 2004). The adaptive cycle was influenced by climatic changes, and different species occupied these areas during the Early Holocene, including hunter and gatherer populations (Bos 2001, Tinner and Lotter 2001, Crombé et al. 2011, Giesecke et al. 2011). During the Mesolithic, hunting and gathering was the subsistence form of life (Uerpmann 2007, Bailey and Spikins 2008, Tolksdorf et al. 2009, Prummel and Niekus 2011); the impact on the soil remained small. When humans settled down and developed agriculture, they increasingly influenced the adaptive cycles of local ecosystems, and the SES agrarian soil use began.

\section{The r-phase of the adaptive cycle: the Neolithic transition in Central Europe}

Agriculture and agrarian soil use spread from the Near East (Davison et al. 2006, Tresset and Vigne 2011). The time of the Neolithic transition varies throughout Europe (Ammerman and Cavalli-Sforza 1971, Gkiasta et al. 2003, Coward et al. 2008). Several approaches exist on how this transition took place; e.g., people practicing agriculture moving in (demic diffusion) or spreading of the agricultural idea (cultural diffusion) over the continent (Haak et al. 2005, Davison et al. 2006, Larson et al. 2007, Gronenborn and Petrasch 2010, Lemmen et al. 2011, Zvelebil et al. 2012, Brandt et al. 2015). Whether demic or cultural diffusion happened, with the Neolithic transition the SES agrarian soil use began. The Neolithic transition marks the onset of the reorganization ( $\alpha$-phase) and the start of the r-phase of the SES agrarian soil use in Central Europe (Fig. 1). The SES variable soil became important to the sedentary people. They cleared forests for timber, fuel, and fields, which changed the water and nutrient cycles, and influenced soil formation processes (Bork et al. 2006, Kaplan et al. 2009, Gerlach and Eckmeier 2012, Ellis et al. 2013). On slopes, the clearing of forests led to erosion and the subsequent formation of anthropogenic colluvial deposit in valleys and depressions along slopes (Leopold and Völkel 2007, Houben 2012, Mitusov et al. 2014). With the beginning of the Neolithic, an increase in slope deposits is visible in Central Europe (Dreibrodt et al. 2010b); e.g., at the Wetterau, Central Germany (Houben et al. 2013), and at Albersdorf, Northern Germany (Reiß et al. 2009). However, anthropogenic colluvial deposits dating to the Neolithic remain scarce, perhaps because erosion was not widespread or because they were redeposited (Zolitschka et al. 2003) or later soil formation processes altered them. However, erosion events are also traceable in lake sediments (e.g., at Lake Belau, Northern Germany), dating to the middle Neolithic (Dreibrodt et al. 2010b).

The SES variable crops emerged during the Neolithic (Table 1). Archaeobotanical analyses show a vegetation change with sedentariness (Rösch 1987). Most of the crops domesticated in the Near East arrived in Europe with the Linear Pottery Culture and the Funnel Beaker Culture (Bakels 2014). The crops grown were similar in all Central European regions (Coward et al. 2008), with einkorn, emmer, wheat, and barley being most common (Herbig 2009, Bogaard et al. 2011, Bogaard et al. 2013). Domesticated animals were also present in Central Europe (Doppler et al. 2015).

The knowledge/technology variable of the SES is indirectly visible in archaeological findings: near Cologne, an excavated well of the Linear Pottery Culture revealed a spade made out of sycamore that dates to 5057 BCE (Mueller 2015). The spade is one of the earliest finds concerning soil cultivation, with the Linear Pottery Culture being the initial phase of the Neolithic (5500-2200 BCE) in Central Europe (Price et al. 2001, Eggert and Samida 2013). Another well excavated at the Baltic Coast of Northern Germany revealed Middle Neolithic artifacts, and archaeobotanical studies indicate agricultural land use (Brozio et al. 2014). The well was used during the Funnel Beaker Culture (4100-2800 BCE), the first sedentary culture in Northern Germany (Kirleis et al. 2012, Brozio et al. 2014, Whitehouse and Kirleis 2014).

Soil quality and proximity to fresh water seem to have been relevant for the settlement of regions (Lüning 2000, Rösch et al. 2002, Zolitschka et al. 2003, Fries 2005, Davison et al. 2006, Banks et al. 2013, Brozio et al. 2014). During the Neolithic, the SES agrarian soil use was in the r-phase of exploitation by transforming the landscape to adjust it to the new human needs connected to sedentariness. The arrival of the crop plants, the development of tools, and the onset of erosion show the emergence of the SES agrarian soil use. However, Gronenborn et al. (2014) propose that during this phase of the general SES agrarian soil use, the Linear Pottery Culture underwent an entire adaptive cycle. This demonstrates that the adaptive cycle consists of different spatial and temporal scales that influence the system as a whole, and takes into account the smaller and faster cycles within social systems that influence the variables of a bigger adaptive cycle (Fath et al. 2015). The adaptive cycle of the Linear Pottery Culture had an influence on the SES agrarian soil use, but the changes within this cycle did not lead to an alteration of the SES itself.

After the Neolithic transition, the SES agrarian soil use remained in the r-phase through the Bronze and Iron Ages. Plow marks in the soil, excavated ards in northern Italy and East Frisia, and rock carvings in northern Italy and Sweden show new agricultural methods and tools (Schultz-Klinken 1981, Tegtmeier 1993, Egg and Pare 1995, Fries 1995, Behre 1998, Zich 1999). The use of metal started with the Bronze Age (2200-800 BC) and continued through the pre-Roman Iron Age (800-15 BC), which consists of the Hallstatt and the La Tène period (Eggert and Samida 2013). Main innovations were sickles during the Bronze Age and scythes during the Iron Age (Jockenhövel 1994, Egg and Pare 1995). The use of metal shows a technological development and an assumed increase in knowledge, which led to mining activities that exploited previously unused natural resources; e.g., in the Black Forest, southwest Germany (Gassmann et al. 2006). The change in the knowledge/technology variable is seen as a development from spade to ard to plow, which can be explained using the approach of Fath et al. (2015) that several small-scale adaptive cycles can affect the r- and K-phase of a bigger cycle. However, 
this knowledge did not develop due to agrarian soil use but was used in an agricultural context later: the late La Tène hoard of Bad Buchau-Kappel in South Germany shows the diversity of iron objects such as pliers, knives, sickles, and scythes (Jockenhövel 1993); tillage tools were not found. In the agriculturally important hoard in Urach, Southern Germany, plow-shares were also absent (Fries 1995). The ards of the type Døstrup, found in Denmark, were used during pre-Roman Iron Age for soils under tillage, while the Walle type ard was used to break up formerly unused soils (Fries 1995). The latter and Early Iron Age ard shares found in the Netherlands (Sanden 1994) point to similar tillage practices in the Bronze and Iron Ages. The results show that metallurgy developed but was not initially used for agricultural purposes. However, in the Bronze Age, cattle traction was established and used for pulling the ard or carts (Bartosiewicz 2013); e.g., facilitating soil cultivation.

The SES variable crops changed little from the Neolithic to the Bronze and Iron Ages (Table 1). However, the soil variable shows an increase in anthropogenic colluvial deposits at the beginning of the Bronze Age and again in the Iron Age (Dreibrodt et al. 2010b). Bronze Age anthropogenic colluvial deposits were found at Albersdorf, Northern Germany (Reiß et al. 2009), at the Frauenberg in Bavaria (Lang et al. 2003), and at the Wetterau, where colluviation also happened during the Early Iron Age (Houben et al. 2013). Turbidites in Black Forest lakes also began in the Bronze Age (Rösch and Tserendorj 2011). The reason for the increased anthropogenic colluviation could be due to more settlements or increased deforestation for fuel purposes for metallurgy.

Research on Celtic fields in the Netherlands indicates an intensive agricultural system in the late Iron Age, with shorter fallow periods, higher manuring intensity, and changes in tillage practices (Spek et al. 2003). The change in management practices and the development of the Celtic fields shows a further development of agriculture (Jankuhn 1977). However, we argue that the SES agrarian soil use remained in the r-phase of exploitation. According to the adaptive cycle proposed by Holling and Gunderson (2002), the creative destruction and reorganization is a fast process. In the archaeological record, in pedological studies, and in palynology, changes are observable. However, these changes are slow, happening over centuries rather than decades. They can be interpreted as tests of the new innovations, which are characteristic of the r-phase (Fath et al. 2015), with entrepreneurial spirit leading to evolving management practices using the innovations. The use of metal indicates a greater knowledge of metallurgy and facilitated work; e.g., bronze sickles and scythes for harvesting. However, the tools used for tillage probably remained similar to the ard found in Walle, East Frisia that dates to the Bronze Age, as the ard shares in the Netherlands suggest (Schultz-Klinken 1981, Sanden 1994, Behre 2000). The development of these tools can be seen as a smaller adaptive cycle that occurred in the SES metallurgy and affected the SES agrarian soil use.

\section{Transition to the K-phase: conservation of agriculture in Central Europe}

In Antiquity, knowledge concerning agriculture was written down and documented. Greek and Roman scholars wrote the first European literary works on agriculture. Among them were
Hesiod's Érga kaì hemérai, Cato's De agri cultura, Varro's Res rusticae, and Columella's De re rustica (quoted from Winiwarter 2006). These works were written mainly for the owners of latifundia; i.e., large landowners (James et al. 2014). Columella described a test to determine soil fertility: after digging a hole, the dug soil was refilled. If the soil formed a mound, the soil was fertile; if the refill formed a hollow, the soil was poor (McNeill and Winiwarter 2004). This approach tests the aggregate stability of a soil, which depends on soil texture, soil organic matter, biological activity, and the mineral content of a soil. The texts show that the SES agrarian soil use moved toward the K- or conservation phase (Fig. 1), with changes within smaller and faster subsystems influencing the adaptive cycle (Fath et al. 2015). The traditions and land management practices were written down, and the importance of "good" practices was stressed. However, it is important to note that the knowledge documented in the literary works of the agrarian writers might not have been applied to agriculture north of the Alps (Deschler-Erb and Akeret 2011), which necessitates historical, archaeological, palynological, and pedological analyses to understand former land use changes.

During the Roman period, Central Europe underwent different developments. In the south and west, the Romans controlled the provinces Germania inferior and superior as well as Raetia (Ausbüttel 2011). The Roman influence led to the establishment of villae rusticae, Roman forts and towns (Heiligmann 1996, Wilson 2006). A villa rustica is an agrarian production center (Groot and Deschler-Erb 2015); for example, in Bavaria, Germany, the production area belonging to one villa was approximately 50 ha (Leopold et al. 2010). In present-day south Germany, villae rusticae were usually established along the Roman roads, which made new areas accessible (Humpert 1995, Kerig and Lechterbeck 2004, Fingerlin 2008). For the area north and east of the Limes, there are few written sources; e.g., Caesars de bello gallico or Ptolemaios Geographike Hyphegesis (Nüsse et al. 2011). It should be noted that those descriptions might reflect stereotypical depictions of "barbarians" (Erdrich 2001). The written sources show a Roman viewpoint, which is in itself valuable, but to understand the SES agrarian soil use and its adaptive cycle, we need to consider all variables. Therefore, interdisciplinary approaches are used, such as the study of the Vecht River valley, located in the present-day Dutch-German border area (van Beek and Groenewoudt 2011). Archaeobotanical analyses show a continuation of the crop variable (Table 1). In southwest Germany, spelt was the most common crop (Rösch 2009).

Analyses at Lake Belau in Schleswig-Holstein and Lake Holzmaar in Rhineland-Palatinate (Dreibrodt et al. 2010b) show the contrast in the soil variable between the two regions. While at Lake Belau soil erosion increased during pre-Roman Iron Age and decreased during the Roman period, which led to a slower input of material into the lake, the situation at Lake Holzmaar was different: the input of material during the period of the Roman Empire was greater than in the pre-Roman Iron Age (Dreibrodt et al. 2010b). Anthropogenic colluvial deposits dating to Roman times are also found at the Kaiserstuhl, southwest Germany (Mäckel et al. 2003). This shows how difficult it is to reconstruct general agricultural practices for Central Europe for that period. Furthermore, the increasing need for building material resulted in deforestation, with its maximum extent 
around $250 \mathrm{CE}$ (Büntgen et al. 2011), which affected soil erosion processes.

Agricultural technology was developed during Roman times, which led, for example, to the use of iron in spades. In presentday Germany, spades are found that date to the 1st to 3rd centuries, and they were fully made of iron (Mueller 2015). In Gallic provinces, a plow with two small wheels, which was pulled by 4-6 oxen, was used (Schneider 2007). Virgil described the "Roman plow" around $1 \mathrm{CE}$, which had iron shares (Lal et al. 2007). The further development of existing tools and the existence of written sources concerning the agricultural practices indicate the K-phase where connectedness increases, including knowledge and technology needed for successful agriculture. The variable soil shows erosion and colluviation processes. However, agrarian soil use was still connected to animal and human power with similar tools. These tools have been improved, but no invention happened that altered the actual practice of agrarian soil use.

The K-phase continued during Medieval times (500-1500 CE), an epoch that comprised many different dynasties, and societal and regional developments (Fried 2009). In Medieval times, the texts of the Roman agricultural writers were still copied. Further, Isidore of Seville wrote a short encyclopedia, which discussed plowing sequence and manuring, and Walafrid Strabo wrote a poem about 24 garden plants (Winiwarter 2006). This shows that certain groups of people wanted to conserve and improve the knowledge of agricultural practices, which indicates the K-phase of the adaptive cycle. However, agricultural practices seem to have relied on traditional practices, which were not necessarily related to the documented knowledge (Dotterweich 2013).

It is suggested that rye became a crop plant during the Medieval period, even though traces of rye were found dating to the Neolithic (Behre 1992). The proportion of the different crops changes over time and from region to region, but the plants used are the ones introduced in the course of the Neolithic/Bronze/ Iron Age/Roman Period (Table 1).

The soil variable was slowly treated differently because fertilization was part of agriculture during Medieval times (Behre 2000). Furthermore, the variables soil and knowledge/technology became interconnected. Plaggen-manuring was practiced in Northern Europe, and ridge and furrow was prevalent (Behre 1976, Blume and Leinweber 2004, Haasis-Berner 2012, van Mourik et al. 2012), traces of which are found in the landscape today. For plaggen-manuring, the topsoil of adjacent areas was cut and distributed on the agricultural fields, which led to the development of heath in the cutting areas and enabled the cultivation of winter rye on the fields (Pape 1970, Behre 2000). The ridge and furrow developed due to the change from the ard to the moldboard or heavy plow, which turned the soil in one direction toward the middle of the field, and permitted agriculture on heavy clay soils (Seidl 2006, Haasis-Berner 2012, Andersen et al. 2016). The microrelief of the ridge and furrow fields enabled agricultural success in dry and moist years. On the ridge, harvest was good even in years with a lot of rainfall, while the furrow provided enough water during a dry year (Linke 1979). The three field system, growing two crops alternating with fallow, also spread and is observable in the archaeobotanical record (Rösch et al. 1992).
Erosion and colluviation increased during Medieval times (Zolitschka et al. 2003, Dreibrodt et al. 2010b, Henkner et al. 2017). Mining activities led to rapid deforestation but also to new regulations prohibiting forest clearing in certain areas (Steuer 1993). Deforestation for agricultural purposes continued, which led to erosion and the formation of anthropogenic colluvial deposits; e.g., in southwestern Germany in the Kraichgau dating to 980-1330 CE (Kadereit et al. 2010), or in the Black Forest around the Krumpenschloß between the 9 th and 15 th century CE (Knopf et al. 2012). In the area of Göttingen, several refilled gullies were discovered in the 1950s (Bork 2006). Research suggests that in 1342, a heavy precipitation event in Central Europe caused erosion in the low mountain ranges that led to the formation of gullies, which were later refilled by pedosediments (Bork et al. 2006). This is supported by a study at the catchment of Lake Belau in Schleswig-Holstein (Dreibrodt 2005) and another study at the Wolfsgraben, Bavaria (Dotterweich et al. 2003, Schmitt et al. 2003). Investigations at the Frickenhauser See, Bavaria show that between 1000 and $1870 \mathrm{CE}$, intensive soil erosion took place (Enters et al. 2006). These archives, thus, show an intensification of land use. However, humans still practiced agriculture with the help of tools and animals used for traction; the SES agrarian soil use was not reconstructed as such but remained in the K-phase.

Soil erosion increased again during the 18th century (Dotterweich 2013), after a phase of land abandonment at the end of the Medieval times (Dreßler et al. 2006, Fraser 2011), which might have happened due to a combination of erosion, crop failure, and the plague. Extreme weather events were documented (Dreibrodt et al. 2010b); e.g., the flood of $1783 / 84$ was reported in newspapers and letters, and was recorded by meteorological stations across Central Europe (Brázdil et al. 2010). Analyses of sedimentation rates of the river Rhine's catchment show increased sedimentation in floodplains and formation of anthropogenic colluvial deposits (Hoffmann et al. 2009).

During the 19th century, the scientific analysis of soil increased. Albrecht Daniel Thaer, Justus von Liebig, Charles Darwin, and Vasilii V. Dokuchaev wrote their important works on soils (Liebig 1841, Thaer 1880, Darwin 1890, Evtuhov 2006). Thaer focused on agriculture and the relevance of humus and crop rotation (Feller et al. 2003b). Liebig tried to develop a mineral fertilizer (Montgomery 2010). Darwin focused on the formation of humus and the importance of worms (Brown et al. 2003, Feller et al. 2003a, Feller et al. 2006, Brevik and Hartemink 2010). Dokuchaev introduced the soil profile, dividing it into A-, B-, and C-horizons, and stressed that soils should be seen as an independent research object (Evtuhov 2006, Brevik and Hartemink 2010). These works show that the variable soil had become a research topic. The variable knowledge was increasingly interlinked with practical soil use, at least considering the landowners, not necessarily the peasants. The increasing knowledge eventually led to the development of new tools, which resulted in the creative destruction and reorganization of the SES agrarian soil use.

\section{The $\Omega$ - and $\alpha$-phase of the social-ecological system agrarian soil use and the beginning of a new cycle}

With industrialization, the SES agrarian soil use moved through the $\Omega$-phase of creative destruction and the $\alpha$-phase of reorganization (Fig. 1). The different variables changed considerably. 
A change in the knowledge/technology variable is observable in new machines, but also resulted in global societal changes. Technological advances, such as the invention of the steam engine, led to motorization and mechanization of agricultural practices (Bergmann 1970, Gessner 1976, Hahn 2011). The machine manufacturer Fowler invented the plowing engine (Seidl 2006), and the blacksmith John Deere marketed a plow that grew in importance with the invention of the tractor (Lal et al. 2007). Increasing knowledge and technology led to new fertilizers. Industrialized nitrogen production using the Haber-Bosch technology increased cereal yield in Germany between 1918 and 1938 by approximately $50 \%$ (Niedertscheider et al. 2014). These developments were closely connected to the use of fossil fuels (Schumacher 1993). The use of new technologies changed the strong link between agriculture and animal husbandry because animals were no longer needed for traction and manure (Lambin et al. 2001). Traditional crop rotation practices and fallow were also abandoned due to cheap nitrogen availability (Montgomery 2010). This development marks the r-phase of exploitation, where growth is accomplished with new efficient technologies. The innovations are tested and entrepreneurial spirit dominates, as proposed by Fath et al. (2015). It also starts the process toward a knowledge-based society, which influenced the agricultural sector (Uekoetter 2012), and raised the workforce in the secondary and tertiary sector (Hahn 2011), which led additionally to urbanization (Antrop 2004) and globalization (Robertson 1992, Levitt 1999). The global trade involves among others, food, fertilizer, fodder, and raw material needed for agriculture and agrarian technology. Information exchange is enabled by the internet and relatively cheap transportation. This global development means that we can no longer consider regional practices when analyzing the SES agrarian soil use.

The SES variable crop changed with the introduction of genetically modified organisms and the widespread use of pesticides, herbicides, and fungicides. Fewer crop plants are used in agriculture today. The crops variable is closely related to the knowledge variable of society because genetically modified organisms developed through human interference (Tiedje et al. 1989, Anklam et al. 2002). Furthermore, society today depends on few crops, namely wheat, rice, and maize (Cassman 1999); e.g., Triticum aestivum became the dominant crop in the 1920s in southwest Germany (Rösch et al. 1992). Monocultures of such crops are a new phenomenon; e.g., rice (Shen et al. 2004).

The soil variable is still prone to erosion but also to other forms of degradation, such as compaction and nutrient depletion. Soil erosion increased with changes in plowing intensities due to bigger and more powerful machines, and heavy machinery enhances soil compaction (Lal et al. 2007). In Europe, an erosion rate of more than $1 \mathrm{tha}^{-1} \mathrm{y}^{-1}$ is regarded as unsustainable (Verheijen et al. 2009). Today, erosion in Europe ranges between 3 and $40 \mathrm{t} \mathrm{ha}^{-1} \mathrm{y}^{-1}$, which is impairing the soil's productivity and is becoming more important as the global population grows (Verheijen et al. 2009).

Another soil-related aspect of the new adaptive cycle is the increase in global fertilizer use by $700 \%$ in the last 40 years (Foley et al. 2005), which has led to changes in the nitrogen and phosphorus cycles (Smil 1999, 2000). While nitrogen can be generated using the Haber-Bosch method, most of the phosphorus used in agriculture is of phosphate rock origin and is nonrenewable. The mining of these reserves, mostly in China, the United States, and Morocco, has tripled since World War II (Cordell et al. 2009), and there was a global increase of $20 \%$ in phosphorus fertilizer use between 2000 and 2008 (MacDonald et al. 2011). Losses of phosphorus and nitrogen affect off-site ecosystems (e.g., eutrophication of lakes and marine ecosystems) and influence global warming and biodiversity; e.g., through $\mathrm{N}_{2} \mathrm{O}, \mathrm{NO}, \mathrm{NO}_{3}$, and $\mathrm{NH}_{3}$ (Tilman et al. 2002, Lal et al. 2011). The carbon cycle also changed with the dependency on fossil fuels, which led to an increase in atmospheric greenhouse gases from $280 \mathrm{ppm} \mathrm{CO}_{2}^{-}$ equivalent at the beginning of industrialization to $430 \mathrm{ppm}$ in 2005 (Falkowski et al. 2000, Aertsens et al. 2013). Present fertilizer production relies on fossil fuels and contributes to $\mathrm{CO}_{2}$ emissions, as does the use of agricultural machinery, land use change in the form of deforestation, and fertilization (Canadell et al. 2007, West et al. 2010).

The dependence on fossil fuels indicates a growing rigidity of the SES, which would point toward the end of the K-phase of the adaptive cycle. However, innovative concepts combine the use of new technology and knowledge with alternative or traditional agricultural practices; e.g., carbon sequestration in soils. Agroforestry, hedgerows, low or no tillage, and cover crops affect erosion, biodiversity, nutrient leaching, soil organic matter, and carbon sequestration (Aertsens et al. 2013). This points toward the small and fast adaptive cycles influencing the big adaptive cycle agrarian soil use and exploring alternative pathways to the challenges of the present. However, the global cropland under no-till is only $9 \%$ (Lal 2013). In present-day Germany, no-tillage is practiced on $1463 \mathrm{~km}^{2}$, equaling $1.3 \%$ of the land base, while conservation or conventional tillage is used on $11,0775 \mathrm{~km}^{2}$ (Statistisches Bundesamt 2016). This shows that even in a highly industrialized country, with rapidly increasing knowledge, no-till is practiced by only a few. This supports the suggestion that we are in the K-phase of conservation because most agrarian soil use depends on mineral fertilizers and tillage practices with big machinery. Whether a new $\Omega$-phase is approaching depends on today's decisions. These rely on studies conducted by different scientists; e.g., concerning the functioning of the nitrogen cycle. A long-term field study in France showed that cover crops reduced nitrogen leaching, while no-till did not result in significant nitrogen sequestration (Constantin et al. 2010). A study in New Zealand showed that the effectiveness of cover crops in preventing nitrogen leaching depended on sowing dates and soil type, and was influenced by weather variability (Teixeira et al. 2016). The results suggest that site-specific practices and holistic management approaches are necessary to develop the agricultural sector toward more sustainability. However, interdisciplinary approaches are needed to communicate these new findings to soil users and society in general, which might also pave the way to greater food security and equality worldwide (Godfray et al. 2010, Lal et al. 2011, Altieri 2012, Scholten 2014). Further, the development in the social component of the SES needs to be investigated in order to determine the effect of small and fast adaptive cycles on the big adaptive cycle of the SES agrarian soil use.

\section{CONCLUSION}

The adaptive cycle narrative is useful for examining the changes occurring in a social-ecological system, such as the changes in the agrarian soil use SES over the last millennia. The narrative helps 
in understanding changes of the SES and within the SES over time, while focusing on important variables, in the presented case, soil, crops, and knowledge/technology. This approach could also be important for archaeological and soil scientific research in general because the concept of SESs and adaptive cycles can be applied to broader developments within social-ecological systems, as shown in this study. It might also be used to connect individual case studies to international contexts.

The adaptive cycle of the SES agrarian soil use started with the Neolithic transition and sedentariness. During the Neolithic, and the Bronze and Iron Ages, the adaptive cycle was in the r-phase. Innovative tools and ideas developed, which enabled the societies to successfully practice agriculture. With Antiquity, the SES moved into the K-phase, where the knowledge concerning agricultural practices was documented by written sources and best practice methods were determined. During Medieval and modern times, the general knowledge, and agricultural knowledge in particular, increased. Furthermore, agricultural tools were improved by, for example, using iron in plow shares, thus incorporating the adaptive cycle of the SES metallurgy. With industrialization, the SES moved through the $\Omega$-phase of release or creative destruction and the $\alpha$-phase of reorganization. The SES changed considerably with the $\alpha$-phase, which led to a separation of animal husbandry and arable farming and a new rphase after the mechanization of agriculture. This is comparable to the establishment of agriculture in the Neolithic due to the big innovations that changed the SES. The Neolithic transition led to sedentariness, so that first settlements and probably new societal structures developed. The Industrial Revolution enabled a diversified society with more people working outside the agrarian business due to the innovations of the r-phase. The knowledge and technology variable are interconnected in both $\mathrm{r}-$ phases; e.g., in the development of the plow and the Haber-Bosch method. After industrialization and mechanization, agrarian soil use no longer involved the work of animals and humans, but work of machines. This has new consequences for the soil variable, comparable to the consequences of deforestation, which subjected the soil to erosion after the establishment of fields since the Neolithic. The new impact on soil includes compaction, nutrient depletion, and other forms of soil degradation. The crops used in agriculture were first introduced in the Neolithic. They were used in different proportions during the last millennia. With industrialization, new genetically modified organisms were developed, thereby connecting the variables crop and knowledge/ technology. The crop variable underwent another change, as society depends on a limited variety of crop plants for nutrition today.

A difference between the two adaptive cycles is the speed of the transition from $\mathrm{r}$ - to K-phase, which lasted several millennia in the first cycle but happened in the course of decades in the second. The increasing knowledge of the first K-phase, which started with the Greek and Roman agricultural writers and culminated among others with Thaer, Liebig, and Darwin, eventually had a vast effect on surplus production and technological development that resulted in a reorganization of the SES and the second adaptive cycle. The knowledge is still increasing steadily, and technological development has led to a high-tech agribusiness that depends on computers, GIS, fertilizers, and more. These new developments also affect the soil and crops used. To investigate these effects, interdisciplinary work is needed to ensure the resilience of the SES agrarian soil use without detrimental effects on soil, crops, knowledge/technology, and climate. These interdisciplinary studies should include various disciplines, among others, soil science, sociology, anthropology, climatology but also history and archaeology, to understand the past developments of and within a region. The SES and adaptive cycle could be used to structure the research in advance due to the focus on specific variables, while also including the systems approach and acknowledging the connection between natural and social systems. Further challenges for these studies are that small-scale and fast adaptive cycles in the social system need to be investigated to understand the development of the big cycle of agrarian soil use. As we are in the K-phase of the adaptive cycle, small and fast adaptive cycles in the social system will determine how long the system remains in the present phase. If innovations and traditions are combined and lessons from the past (e.g., concerning erosion) are learned, the new K-phase might last for an extended time. However, if this does not happen, a new $\Omega$-phase might result in a reorganization of the system with an unknown outcome. The variety of possible responses to global, regional, and local challenges requires scientists from different fields to investigate the different variables of the SES agrarian soil use to understand the processes and interactions between and within the variables. This might contribute to the resilience of the SES and lead to new policies on a global scale. Interdisciplinary research helped us understand the adaptive cycle of the SES from the Neolithic to industrialization. It is also necessary to develop a resilient agrarian soil use for the future.

\section{Responses to this article can be read online at: http://www.ecologyandsociety.org/issues/responses. $\mathrm{php} / 9729$}

\section{Acknowledgments:}

We thank the anonymous reviewers for their valuable comments on the manuscript. The corresponding author is grateful for a scholarship of the University of Tübingen and the discussions within the SFB 1070 RESOURCECULTURE. We thank Richard Szydlak for his help with the figure and Adriane Michaelis for improving the language of the manuscript. We further acknowledge support by Deutsche Forschungsgemeinschaft and Open Access Publishing Fund of University of Tübingen.

\section{LITERATURE CITED}

Aertsens, J., L. de Nocker, and A. Gobin. 2013. Valuing the carbon sequestration potential for European agriculture. Land Use Policy 31:584-594. http://dx.doi.org/10.1016/j.landusepol.2012.09.003

Allison, H. E., and R. J. Hobbs. 2004. Resilience, adaptive capacity, and the "lock-in trap" of the Western Australian agricultural region. Ecology and Society 9(1):3. http://dx.doi. org/10.5751/ES-00641-090103

Altieri, M. A. 2012. Convergence or divide in the movement for sustainable and just agriculture. Pages 1-9 in E. Lichtfouse, editor. Organic fertilisation, soil quality and human health. Springer, Netherlands. http://dx.doi.org/10.1007/978-94-007-4113-3 1 
Ammerman, A. J., and L. L. Cavalli-Sforza. 1971. Measuring the rate of spread of early farming in Europe. Man, New Series 6 (4):674-688. http://dx.doi.org/10.2307/2799190

Andersen, T. B., P. S. Jensen, and C. V. Skovsgaard. 2016. The heavy plow and the agricultural revolution in Medieval Europe. Journal of Development Economics 118:133-149. http://dx.doi. org/10.1016/j.jdeveco.2015.08.006

Anklam, E., F. Gadani, P. Heinze, H. Pijnenburg, and G. van den Eede. 2002. Analytical methods for detection and determination of genetically modified organisms in agricultural crops and plantderived food products. European Food Research and Technology 214(1):3-26. http://dx.doi.org/10.1007/s002170100415

Antrop, M. 2004. Landscape change and the urbanization process in Europe. Landscape and Urban Planning 67(1-4):9-26. http:// dx.doi.org/10.1016/S0169-2046(03)00026-4

Aranbarri, J., P. González-Sampériz, B. Valero-Garcés, A. Moreno, G. Gil-Romera, M. Sevilla-Callejo, E. García-Prieto, F. Di Rita, M. P. Mata, M. Morellón, et al. 2014. Rapid climatic changes and resilient vegetation during the Lateglacial and Holocene in a continental region of south-western Europe. Global and Planetary Change 114:50-65. http://dx.doi.org/10.1016/j. gloplacha.2014.01.003

Auerswald, K., P. Fiener, and R. Dikau. 2009. Rates of sheet and rill erosion in Germany - a meta-analysis. Geomorphology 111(34):182-193. http://dx.doi.org/10.1016/j.geomorph.2009.04.018

Ausbüttel, F. M. 2011. Die Gründung und Teilung der Provinz Germania. Klio - Beiträge zur Alten Geschichte 93(2):392-410. http://dx.doi.org/10.1524/klio.2011.0022

Bailey, G., and P. Spikins, editors. 2008. Mesolithic Europe. Cambridge University Press, New York, USA.

Bakels, C. 2014. The first farmers of the Northwest European Plain: some remarks on their crops, crop cultivation and impact on the environment. Journal of Archaeological Science 51:94-97. http://dx.doi.org/10.1016/j.jas.2012.08.046

Banks, W. E., N. Antunes, S. Rigaud, and F. d'Errico. 2013. Ecological constraints on the first prehistoric farmers in Europe. Journal of Archaeological Science 40(6):2746-2753. http://dx.doi. org/10.1016/j.jas.2013.02.013

Bartosiewicz, L. 2013. Animals in Bronze Age Europe. In H. Fokkens and A. Harding, editors. The Oxford handbook of the European Bronze Age. Oxford University Press, Oxford. http://dx. doi.org/10.1093/oxfordhb/9780199572861.013.0018

Battisti, D. S., and R. L. Naylor. 2009. Historical warnings of future food insecurity with unprecedented seasonal heat. Science 323:240-244. http://dx.doi.org/10.1126/science.1164363

Behre, K.-E. 1976. Beginn und Form der Plaggenwirtschaft in Nordwestdeutschland nach pollenanalytischen Untersuchungen in Ostfriesland. Neue Ausgrabungen und Forschungen in Niedersachsen 10:197-224.

Behre, K.-E. 1992. The history of rye cultivation in Europe. Vegetation History and Archaeobotany 1:141-156. http://dx.doi. org/10.1007/BF00191554

Behre, K.-E. 1998. Landwirtschaftliche Entwicklungslinien und die Veränderung der Kulturlandschaft in der Bronzezeit Europas.
In B. Hänsel, editor. Mensch und Umwelt in der Bronzezeit Europas. Oetker-Voges Verlag, Kiel.

Behre, K.-E. 2000. Frühe Ackersysteme, Düngemethoden und die Entstehung der Nordwestdeutschen Heiden. Archäologisches Korrespondenzblatt 30:135-151.

Beier, C. M., A. L. Lovecraft, and F. S. Chapin, III. 2009. Growth and collapse of a resource system: an adaptive cycle of change in public lands governance and forest management in Alaska. Ecology and Society 14(2):5. http://dx.doi.org/10.5751/ES-02955-140205

Berglund, B. E. 2003. Human impact and climate changessynchronous events and a causal link? Quaternary International 105(1):7-12. http://dx.doi.org/10.1016/S1040-6182(02)00144-1

Bergmann, K. 1970. Agrarromantik und Großstadtfeindschaft. Verlag Anton Hain, Meisenheim am Glan.

Berkes, F. 2004. Rethinking community-based conservation. Conservation Biology 18(3):621-630.

Berkes, F., J. Colding, and C. Folke, editors. 2003. Navigating social-ecological systems: building resilience for complexity and change. Cambridge University Press, Cambridge, UK.

Berkes, F., and C. Folke, editors. 1998. Linking social and ecological systems: management practices and social mechanisms for building resilience. Cambridge University Press, Cambridge, $\mathrm{UK}$.

Blum, W. E., and H. Eswaran. 2004. Soils for sustaining global food production. Journal of Food Science 69(2):37-42. http://dx. doi.org/10.1111/j.1365-2621.2004.tb15490.x

Blume, H.-P., and P. Leinweber. 2004. Plaggen soils: landscape history, properties, and classification. Journal of Plant Nutrition and Soil Science 167(3):319-327. http://dx.doi.org/10.1002/ jpln.200420905

Bogaard, A., R. Fraser, T. H. E. Heaton, M. Wallace, P. Vaiglova, M. Charles, G. Jones, R. P. Evershed, A. K. Styring, N. H. Andersen, et al. 2013. Crop manuring and intensive land management by Europe's first farmers. Proceedings of the National Academy of Sciences of the United States of America 110(31):12589-12594. http://dx.doi.org/10.1073/pnas.1305918110

Bogaard, A., R. Krause, and H.-C. Strien. 2011. Towards a social geography of cultivation and plant use in an early farming community: Vaihingen an der Enz south-west Germany. Antiquity 85:395-416. http://dx.doi.org/10.1017/S0003598X00067831

Bork, H.-R. 2006. Landschaften der Erde unter dem Einfluss des Menschen. Primus Verlag (Wissenschaftliche Buchgesellschaft), Darmstadt.

Bork, H.-R., S. Dreibrodt, and A. Mieth. 2006. Die langfristigen Wirkungen von Witterungsextremen auf Umwelt und Gesellschaft. Pages 11-22 in Klimawandel - Klimafolgen Naturkatastrophen und deren Auswirkungen auf Umwelt und Gesellschaft (Rostock, 20.10.2006), Rostock.

Bos, J. A. 2001. Lateglacial and Early Holocene vegetation history of the northern Wetterau and the Amöneburger Basin (Hessen), central-west Germany. Review of Palaeobotany and Palynology 115(3-4):177-204. http://dx.doi.org/10.1016/S0034-6667(01)00069-0 
Brandt, G., A. Szécsényi-Nagy, C. Roth, K. W. Alt, and W. Haak. 2015. Human paleogenetics of Europe--the known knowns and the known unknowns. Journal of Human Evolution 79:73-92. http://dx.doi.org/10.1016/j.jhevol.2014.06.017

Brázdil, R., G. R. Demarée, M. Deutsch, E. Garnier, A. Kiss, J. Luterbacher, N. Macdonald, C. Rohr, P. Dobrovolný, P. Kolář, and K. Chromá. 2010. European floods during the winter 1783/1784: scenarios of an extreme event during the 'Little Ice Age'. Theoretical and Applied Climatology 100(1-2):163-189. http://dx.doi.org/10.1007/s00704-009-0170-5

Brevik, E. C., and A. E. Hartemink. 2010. Early soil knowledge and the birth and development of soil science. Catena 83:23-33. http://dx.doi.org/10.1016/j.catena.2010.06.011

Brown, G. G., C. Feller, E. Blanchart, P. Deleporte, and S. S. Chernyanskii. 2003. With Darwin, earthworms turn intelligent and become human friends: the 7 th international symposium on earthworm ecology, Cardiff, Wales, 2002. Pedobiologia 47(56):924-933. http://dx.doi.org/10.1078/0031-4056-00282

Brozio, J. P., W. Dörfler, I. Feeser, W. Kirleis, S. Klooß, and J. Müller. 2014. A Middle Neolithic well from Northern Germany: a precise source to reconstruct water supply management, subsistence economy, and deposition practices. Journal of Archaeological Science 51:135-153. http://dx.doi.org/10.1016/j. jas.2013.03.029

Büntgen, U., W. Tegel, K. Nicolussi, M. McCormick, D. Frank, V. Trouet, J. O. Kaplan, F. Herzig, K.-U. Heussner, H. Wanner, et al. 2011. 2500 years of European climate variability and human susceptibility. Science 331:578-582. http://dx.doi.org/10.1126/ science. 1197175

Canadell, J. G., C. Le Quéré, M. R. Raupach, C. B. Field, E. T. Buitenhuis, P. Ciais, T. J. Conway, N. P. Gillett, R. A. Houghton, and G. Marland. 2007. Contributions to accelerating atmospheric $\mathrm{CO}_{2}$ growth from economic activity, carbon intensity, and efficiency of natural sinks. Proceedings of the National Academy of Sciences of the United States of America 104(47):18866-18870. http://dx.doi.org/10.1073/pnas.0702737104

Carpenter, S., B. Walker, J. M. Anderies, and N. Abel. 2001. From metaphor to measurement: resilience of what to what? Ecosystems 4(8):765-781. http://dx.doi.org/10.1007/s10021-001-0045-9

Caseldine, C. J., and C. Turney. 2010. The bigger picture: towards integrating palaeoclimate and environmental data with a history of societal change. Journal of Quaternary Science 25(1):88-93. http://dx.doi.org/10.1002/jqs. 1337

Cassman, K. G. 1999. Ecological intensification of cereal production systems: yield potential, soil quality, and precision agriculture. Proceedings of the National Academy of Sciences of the United States of America 96(11):5952-5959. http://dx.doi. org/10.1073/pnas.96.11.5952

Childe, V. G. 1936. Man makes himself. Watts, London, UK.

Constantin, J., B. Mary, F. Laurent, G. Aubrion, A. Fontaine, P. Kerveillant, and N. Beaudoin. 2010. Effects of catch crops, no till and reduced nitrogen fertilization on nitrogen leaching and balance in three long-term experiments. Agriculture, Ecosystems \& Environment 135(4):268-278. http://dx.doi.org/10.1016/j. agee.2009.10.005
Cordell, D., J.-O. Drangert, and S. White. 2009. The story of phosphorus: global food security and food for thought. Global Environmental Change 19(2):292-305. http://dx.doi.org/10.1016/ j.gloenvcha.2008.10.009

Costanza, R., L. Graumlich, W. Steffen, C. Crumley, J. Dearing, K. Hibbard, R. Leemans, C. Redman, and D. Schimel. 2007. Sustainability or collapse: What can we learn from integrating the history of humans and the rest of nature? Ambio 36(7):522-527. http://dx.doi.org/10.1579/0044-7447(2007)36[522:SOCWCW]2.0. $\mathrm{CO} ; 2$

Coward, F., S. Shennan, S. Colledge, J. Conolly, and M. Collard. 2008. The spread of Neolithic plant economies from the Near East to northwest Europe: a phylogenetic analysis. Journal of Archaeological Science 35(1):42-56. http://dx.doi.org/10.1016/j. jas.2007.02.022

Crombé, P., J. Sergant, E. Robinson, and J. de Reu. 2011. Huntergatherer responses to environmental change during the Pleistocene-Holocene transition in the southern North Sea basin: final Palaeolithic-final Mesolithic land use in northwest Belgium. Journal of Anthropological Archaeology 30(3):454 471. http://dx. doi.org/10.1016/j.jaa.2011.04.001

Darwin, C. 1890. The Formation of vegetable mould through the action of worms with observation on their habits. D. Appleton \& Company, New York, USA.

Davison, K., P. Dolukhanov, G. R. Sarson, and A. Shukurov. 2006. The role of waterways in the spread of the Neolithic. Journal of Archaeological Science 33(5):641-652. http://dx.doi.org/10.1016/ j.jas.2005.09.017

Deschler-Erb, S., and Ö. Akeret. 2011. Archäobiologische Forschungen zum römischen Legionslager von Vindonissa und seinem Umland: Status quo und Potenzial. Jahresbericht Gesellschaft Pro Vindonissa:13-36.

Doppler, T., C. Gerling, V. Heyd, C. Knipper, T. Kuhn, M. F. Lehmann, A. W. Pike, and J. Schibler. 2015. Landscape opening and herding strategies: carbon isotope analyses of herbivore bone collagen from the Neolithic and Bronze Age lakeshore site of Zurich-Mozartstrasse, Switzerland. Quaternary International 436 (Part B):18-28. http://dx.doi.org/10.1016/j.quaint.2015.09.007

Dorren, L. K. A., and A. C. Imeson. 2005. Soil erosion and the adaptive cycle metaphor. Land Degradation \& Development 16 (6):509-516. http://dx.doi.org/10.1002/ldr.705

Dotterweich, M. 2013. The history of human-induced soil erosion: geomorphic legacies, early descriptions and research, and the development of soil conservation-a global synopsis. Geomorphology 201:1-34. http://dx.doi.org/10.1016/j. geomorph.2013.07.021

Dotterweich, M., A. Schmitt, G. Schmidtchen, and H.-R. Bork. 2003. Quantifying historical gully erosion in northern Bavaria. Catena 50:135-150. http://dx.doi.org/10.1016/S0341-8162(02) 00142-X

Dreibrodt, S. 2005. Detecting heavy precipitation events during the Holocene from soils, gully fills, colluvia and lake sediments examples from the Belauer See catchment (northern Germany). Zeitschrift der Deutschen Gesellschaft für Geowissenschaften 156 (4):573-588. http://dx.doi.org/10.1127/1860-1804/2005/0156-0573 
Dreibrodt, S., J. Lomax, O. Nelle, C. Lubos, P. Fischer, A. Mitusov, S. Reiss, U. Radtke, M. Nadeau, P. Meiert Grootes, and H.-R. Bork. 2010a. Are mid-latitude slopes sensitive to climatic oscillations? Implications from an Early Holocene sequence of slope deposits and buried soils from eastern Germany. Geomorphology 122:351-369. http://dx.doi.org/10.1016/j. geomorph.2010.05.015

Dreibrodt, S., C. Lubos, B. Terhorst, B. Damm, and H.-R. Bork. $2010 \mathrm{~b}$. Historical soil erosion by water in Germany: scales and archives, chronology, research perspectives. Quaternary International 222(1-2):80-95. http://dx.doi.org/10.1016/j. quaint.2009.06.014

Dreßler, M., U. Selig, W. Dörfler, S. Adler, H. Schubert, and T. Hübener. 2006. Environmental changes and the Migration Period in northern Germany as reflected in the sediments of Lake Dudinghausen. Quaternary Research 66(1):25-37. http://dx.doi. org/10.1016/j.yqres.2006.02.007

Dreslerová, D., P. Kočár, T. Chuman, L. Šefrna, and Š. Poništiak. 2013. Variety in cereal cultivation in the Late Bronze and Early Iron Ages in relation to environmental conditions. Journal of Archaeological Science 40(4):1988-2000.

Eckmeier, E., M. Rösch, O. Ehrmann, M. W. Schmidt, W. Schier, and R. Gerlach. 2007. Conversion of biomass to charcoal and the carbon mass balance from a slash-and-burn experiment in a temperate deciduous forest. The Holocene 17(4):539-542. http:// dx.doi.org/10.1177/0959683607077041

Egg, M., and C. Pare. 1995. Die Metallzeiten in Mitteleuropa und im Vorderen Orient: Die Abteilung Vorgeschichte im RömischGermanischen Zentralmuseum. Verlag des Römisch-Germanischen Zentralmuseums, Mainz.

Eggert, M. K. H., and S. Samida. 2013. Ur-und Frühgeschichtliche Archäologie. 2. Auflage edition. Narr Francke Attempto Verlag $\mathrm{GmbH}+\mathrm{Co.KG}$, Tübingen.

Ellis, E. C., J. O. Kaplan, D. Q. Fuller, S. Vavrus, K. Klein Goldewijk, and P. H. Verburg. 2013. Used planet: a global history. Proceedings of the National Academy of Sciences of the United States of America 110(20):7978-7985. http://dx.doi.org/10.1073/ pnas. 1217241110

Enters, D., A. Lücke, and B. Zolitschka. 2006. Effects of land-use change on deposition and composition of organic matter in Frickenhauser See, northern Bavaria, Germany. Science of the Total Environment 369(1-3):178-187. http://dx.doi.org/10.1016/j. scitotenv.2006.05.020

Erdrich, M. 2001. Rom und die Barbaren: Das Verhältnis zwischen dem Imperium Romanum und den germanischen Stämmen vor seiner Nordwestgrenze von der späten römischen Republik bis zum Gallischen Sonderreich. Philipp von Zabern, Mainz.

Evans, S. 2012. Agricultural production and environmental history. In J. M. Pilcher, editor. The Oxford handbook of food history. Oxford University Press, Oxford. http://dx.doi. org/10.1093/oxfordhb/9780199729937.013.0012

Evtuhov, C. 2006. The roots of Dokuchaev's scientific contributions: cadastral soil mapping and agro-environmental issues. Pages 125-148 in B. P. Warkentin, editor. Footprints in the soil: people and ideas in soil history. Elsevier, Amsterdam, Oxford.
Falkowski, P., R. J. Scholes, E. Boyle, J. Canadell, D. Canfield, J. Elser, N. Gruber, K. Hibbard, P. Högberg, S. Linder, et al. 2000. The global carbon cycle: a test of our knowledge of Earth as a system. Science 290:291-296. http://dx.doi.org/10.1126/ science.290.5490.291

Fath, B. D., C. A. Dean, and H. Katzmair. 2015. Navigating the adaptive cycle: an approach to managing the resilience of social systems. Ecology and Society 20(2):24. http://dx.doi.org/10.5751/ ES-07467-200224

Feller, C., E. Blanchart, and D. H. Yaalon. 2006. Some major scientists (Palissy, Buffon, Thaer, Darwin and Muller) have described soil profiles and developed soil survey techniques before 1883. Pages 85-105 in B. P. Warkentin, editor. Footprints in the soil: people and ideas in soil history. Elsevier, Amsterdam, Oxford.

Feller, C., G. G. Brown, E. Blanchart, P. Deleporte, and S. S. Chernyanskii. 2003a. Charles Darwin, earthworms and the natural sciences: various lessons from past to future. Agriculture, Ecosystems \& Environment 99(1-3):29-49. http://dx.doi. org/10.1016/S0167-8809(03)00143-9

Feller, C. L., L. J.-M. Thuriès, R. J. Manlay, P. Robin, and E. Frossard. 2003b. "The principles of rational agriculture" by Albrecht Daniel Thaer (1752-1828). An approach to the sustainability of cropping systems at the beginning of the 19th century. Journal of Plant Nutrition and Soil Science 166(6):687698.

Fingerlin, G. 2008. Vom Oberrhein zur jungen Donau: Die Straße durch den südlichen Schwarzwald in keltischer, römischer und frühmittelalterlicher Zeit. Die Schriften des Vereins für Geschichte und Naturgeschichte der Baar 51:47-58.

Foley, J. A., R. DeFries, G. P. Asner, C. Barford, G. Bonan, S. R. Carpenter, F. S. Chapin, M. T. Coe, G. C. Daily, H. K. Gibbs, et al. 2005. Global consequences of land use. Science 309:570-574. http://dx.doi.org/10.1126/science.1111772

Foley, J. A., N. Ramankutty, K. A. Brauman, E. S. Cassidy, J. S. Gerber, M. Johnston, N. D. Mueller, C. O'Connell, D. K. Ray, P. C. West, et al. 2011. Solutions for a cultivated planet. Nature 478:337-342. http://dx.doi.org/10.1038/nature10452

Fraser, E. D. 2011. Can economic, land use and climatic stresses lead to famine, disease, warfare and death? Using Europe's calamitous 14th century as a parable for the modern age. Ecological Economics 70(7):1269-1279. http://dx.doi.org/10.1016/ j.ecolecon.2010.02.010

Fried, J. 2009. Das Mittelalter: Geschichte und Kultur. 3. Auflage edition. C.H. Beck, München.

Fries, J. C. 1995. Vor-und frühgeschichtliche Agrartechnik auf den Britischen Inseln und dem Kontinent: Eine vergleichende Studie. Verlag Marie Leidorf GmbH, Espelkamp.

Fries, J. E. 2005. Methodische Überlegungen zur Ressource Boden. Archäologische Informationen 28(1\&2):139-147.

Gassmann, G., M. Rösch, and G. Wieland. 2006. Das Neuenbürger Erzrevier im Nordschwarzwald als Wirtschaftsraum während der Späthallstatt- und Frühlatènezeit. Germania 84:273306. 
Gauthier, E., and H. Richard. 2009. Bronze Age at Lake Bourget (NW Alps, France): vegetation, human impact and climatic change. Quaternary International 200(1-2):111-119.

Geißler, C., P. Kühn, M. Böhnke, H. Bruelheide, X. Shi, and T. Scholten. 2012. Splash erosion potential under tree canopies in subtropical SE China. Catena 91:85-93. http://dx.doi. org/10.1016/j.catena.2010.10.009

Gerlach, R., and E. Eckmeier. 2012. Prehistoric land use and its impact on soil formation since Early Neolithic. Examples from the Lower Rhine Area. Pages 11-16 in W. Bebermeier, R. Hebenstreit, E. Kaiser, and J. Krause, editors. Landscape archaeology. Proceedings of the International Conference, 6-8 June 2012, Berlin, Germany.

Gessner, D. 1976. Agrarverbände in der Weimarer Republik: Wirtschaftliche und soziale Voraussetzungen agrarkonservativer Politik vor 1933. Dissertation. Universität Köln, Köln.

Giesecke, T., K. D. Bennett, H. J. B. Birks, A. E. Bjune, E. Bozilova, A. Feurdean, W. Finsinger, C. Froyd, P. Pokorný, M. Rösch, et al. 2011. The pace of Holocene vegetation change testing for synchronous developments. Quaternary Science Reviews 30(19-20):2805-2814. http://dx.doi.org/10.1016/j. quascirev.2011.06.014

Gkiasta, M., T. Russell, S. Shennan, and J. Steele. 2003. Neolithic transition in Europe: the radiocarbon record revisited. Antiquity 77(295):45-62. http://dx.doi.org/10.1017/S0003598X00061330

Godfray, H. C. J., J. R. Beddington, I. R. Crute, L. Haddad, D. Lawrence, J. F. Muir, J. Pretty, S. Robinson, S. M. Thomas, and C. Toulmin. 2010. Food security: the challenge of feeding 9 billion people. Science 327:812-818. http://dx.doi.org/10.1126/science.1185383

Gronenborn, D., and J. Petrasch, editors. 2010. Die Neolithisierung Mitteleuropas: Internationale Tagung, Mainz 24. bis 26. Juni 2005. Verlag des Römisch-Germanischen Zentralmuseums Mainz.

Gronenborn, D., H.-C. Strien, S. Dietrich, and F. Sirocko. 2014. 'Adaptive cycles' and climate fluctuations: a case study from Linear Pottery Culture in western Central Europe. Journal of Archaeological Science 51:73-83. http://dx.doi.org/10.1016/j. jas.2013.03.015

Groot, M., and S. Deschler-Erb. 2015. Market strategies in the Roman provinces: different animal husbandry systems explored by a comparative regional approach. Journal of Archaeological Science: Reports 4:447-460. http://dx.doi.org/10.1016/j.jasrep.2015.10.007

Grundmann, P., M.-H. Ehlers, and G. Uckert. 2012. Responses of agricultural bioenergy sectors in Brandenburg (Germany) to climate, economic and legal changes: an application of Holling's adaptive cycle. Energy Policy 48:118-129. http://dx.doi. org/10.1016/j.enpol.2012.04.051

Gunderson, L. H., and C. S. Holling, editors. 2002. Panarchy: understanding transformations in human and natural systems. Island Press, Washington, D.C., USA.

Haak, W., P. Forster, B. Bramanti, S. Matsumura, G. Brandt, M. Tänzer, R. Villemy, C. Renfrew, D. Gronenborn, K. W. Alt, and J. Burger. 2005. Ancient DNA from the first European farmers in 7500-year-old Neolithic sites. Science 310:1016-1018.
Haasis-Berner, A. 2012. Relikte mittelalterlicher Landnutzung: Der ehemalige Ort Mauchen (Lkr. Breisgau-Hochschwarzwald). Denkmalpflege in Baden-Württemberg. Nachrichtenblatt des Landesdenkmalamtes(1):54-55.

Hahn, H.-W. 2011. Die Industrielle Revolution in Deutschland. Oldenbourg Wissenschaftsverlag $\mathrm{GmbH}$, München.

Hawkes, J. G., and J. Francisco-Ortega. 1993. The early history of the potato in Europe. Euphytica 70:1-7. http://dx.doi. org/10.1007/BF00029633

Heiligmann, J. 1996. Vormarsch auf die Schwäbische Alb: Das Kastell Urspring in Ulmer Museum, editor. Römer an Donau und Iller: Neue Forschungen und Funde. Jan Thorbecke Verlag GmbH \& Co., Sigmaringen.

Henkner, J., J. J. Ahlrichs, S. S. Downey, M. Fuchs, B. R. James, T. Knopf, T. Scholten, S. Teuber, and P. Kühn. 2017. Archaeopedology and chronostratigraphy of colluvial deposits as a proxy for regional land use history (Baar, southwest Germany). Catena 155:93-113. http://dx.doi.org/10.1016/j. catena.2017.03.005

Herbig, C. 2009. Recent archaeobotanical investigations into the range and abundance of Neolithic crop plants in settlements around Lake Constance and in Upper Swabia (south-west Germany) in relation to cultural influences. Journal of Archaeological Science 36(6):1277-1285. http://dx.doi.org/10.1016/ j.jas.2009.01.024

Hjelle, K. L., T. Solem, L. S. Halvorsen, and L. I. Åstveit. 2012. Human impact and landscape utilization from the Mesolithic to Medieval time traced by high spatial resolution pollen analysis and numerical methods. Journal of Archaeological Science0 39 (5):1368-1379.

Hoffmann, T., G. Erkens, R. Gerlach, J. Klostermann, and A. Lang. 2009. Trends and controls of Holocene floodplain sedimentation in the Rhine catchment. Catena 77(2):96-106. http://dx.doi.org/10.1016/j.catena.2008.09.002

Holling, C. S. 2001. Understanding the complexity of economic, ecological, and social systems. Ecosystems 4(5):390-405. http:// dx.doi.org/10.1007/s10021-001-0101-5

Holling, C. S., and L. H. Gunderson. 2002. Resilience and adaptive cycles. Pages 25-62 in L. H. Gunderson and C. S. Holling, editors. Panarchy: understanding transformations in human and natural systems. Island Press, Washington, D.C., USA.

Holling, C. S., L. H. Gunderson, and D. Ludwig. 2002a. In quest of a theory of adaptive change. Pages 3-22 in L. H. Gunderson and C. S. Holling, editors. Panarchy: understanding transformations in human and natural systems. Island Press, Washington, D.C., USA.

Holling, C. S., L. H. Gunderson, and G. D. Peterson. $2002 b$. Sustainability and panarchies. Pages 63-103 in L. H. Gunderson and C. S. Holling, editors. Panarchy: understanding transformations in human and natural systems. Island Press, Washington, D.C., USA.

Houben, P. 2012. Sediment budget for five millennia of tillage in the Rockenberg catchment (Wetterau loess basin, Germany). Quaternary Science Reviews 52:12-23. http://dx.doi.org/10.1016/ j.quascirev.2012.07.011 
Houben, P., M. Schmidt, B. Mauz, A. Stobbe, and A. Lang. 2013. Asynchronous Holocene colluvial and alluvial aggradation: a matter of hydrosedimentary connectivity. The Holocene 23 (4):544-555. http://dx.doi.org/10.1177/0959683612463105

Hubbard, R. N. L. B. 1980. Development of agriculture in Europe and the Near East: evidence from quantitative studies. Economic Botany 34(1):51-67.

Hublin, J.-J. 2015. The modern human colonization of western Eurasia: when and where? Quaternary Science Reviews 118:194 210. http://dx.doi.org/10.1016/j.quascirev.2014.08.011

Hughes, P. D., and P. L. Gibbard. 2015. A stratigraphical basis for the Last Glacial Maximum (LGM). Quaternary International 383:174-185. http://dx.doi.org/10.1016/j.quaint.2014.06.006

Humpert, J. 1995. Ziele und Methoden der Altwegeforschung am Beispiel einer römischen Straße von der Baar in den Breisgau. Die Schriften des Vereins für Geschichte und Naturgeschichte der Baar 38:11-23.

James, B. R., W. E. Blum, and C. Dazzi. 2014. Bread and soil in ancient Rome: a vision of abundance and an ideal of order based on wheat, grapes, and olives. Pages 153-174 in G. J. Churchman and E. R. Landa, editors. The soil underfoot: infinite possibilities for a finite resource. CRC Press. http://dx.doi.org/10.1201/ $\underline{\text { b16856-16 }}$

Jankuhn, H. 1977. Einführung in die Siedlungsarchäologie. Walter de Gruyter, Berlin, New York, USA.

Jockenhövel, A. 1993. Eisengewinnung im Mittelgebirgsraum. Pages 70-74 in H. Steuer and U. Zimmermann, editors. Alter Bergbau in Deutschland. Konrad Theiss Verlag, Stuttgart.

Jockenhövel, A. 1994. Umwelt - Landwirtschaft - Ernährung in A. Jockenhövel and W. Kubach, editors. Bronzezeit in Deutschland. Konrad Theiss Verlag, Stuttgart.

Kadereit, A., P. Kühn, and G. A. Wagner. 2010. Holocene relief and soil changes in loess-covered areas of south-western Germany: the pedosedimentary archives of Bretten-Bauerbach (Kraichgau). Quaternary International 222(1-2):96-119. http:// dx.doi.org/10.1016/j.quaint.2009.06.025

Kanstrup, M., M. K. Holst, P. M. Jensen, I. K. Thomsen, and B. T. Christensen. 2014. Searching for long-term trends in prehistoric manuring practice. $\delta 15 \mathrm{~N}$ analyses of charred cereal grains from the 4th to the 1st millennium BC. Journal of Archaeological Science 51:115-125.

Kaplan, J. O., K. M. Krumhardt, and N. Zimmermann. 2009. The prehistoric and preindustrial deforestation of Europe. Quaternary Science Reviews 28:3016-3034. http://dx.doi. org/10.1016/j.quascirev.2009.09.028

Kerig, T., and J. Lechterbeck. 2004. Laminated sediments, human impact, and a multivariate approach: a case study in linking palynology and archaeology (Steisslingen, Southwest Germany). Quaternary International 113(1):19-39. http://dx.doi.org/10.1016/ S1040-6182(03)00078-8

Kirleis, W., S. Klooß, H. Kroll, and J. Müller. 2012. Crop growing and gathering in the northern German Neolithic: a review supplemented by new results. Vegetation History and
Archaeobotany 21(3):221-242. http://dx.doi.org/10.1007/ s00334-011-0328-9

Knopf, T., T. Baum, T. Scholten, and P. Kühn. 2012. Landnutzung im Frühen Mittelalter: Eine Archäopedologische Prospektion im Mittleren Schwarzwald. Archäologisches Korrespondenzblatt 42 (1):123-133.

Lal, R. 2010. Managing soils for a warming earth in a foodinsecure and energy-starved world. Journal of Plant Nutrition and Soil Science 173(1):4-15. http://dx.doi.org/10.1002/jpln.200900290

Lal, R. 2013. Enhancing ecosystem services with no-till. Renewable Agriculture and Food Systems 28(02):102-114. http:// dx.doi.org/10.1017/S1742170512000452

Lal, R., J. A. Delgado, P. M. Groffman, N. Millar, C. Dell, and A. Rotz. 2011. Management to mitigate and adapt to climate change. Journal of Soil and Water Conservation 66(4):276-285. http://dx.doi.org/10.2489/jswc.66.4.276

Lal, R., D. C. Reicosky, and J. D. Hanson. 2007. Evolution of the plow over 10,000 years and the rationale for no-till farming. Soil and Tillage Research 93(1):1-12. http://dx.doi.org/10.1016/j. $\underline{\text { still.2006.11.004 }}$

Lambin, E. F., B. L. Turner, H. J. Geist, S. B. Agbola, A. Angelsen, J. W. Bruce, O. T. Coomes, R. Dirzo, G. Fischer, C. Folke, et al. 2001. The causes of land-use and land-cover change: moving beyond the myths. Global Environmental Change 11(4):261-269. http://dx.doi.org/10.1016/S0959-3780(01)00007-3

Lang, A. 2003. Phases of soil erosion-derived colluviation in the loess hills of South Germany. Catena 51(3-4):209-221. http://dx. doi.org/10.1016/S0341-8162(02)00166-2

Lang, A., H.-P. Niller, and M. M. Rind. 2003. Land degradation in Bronze Age Germany: archaeological, pedological, and chronometrical evidence from a hilltop settlement on the Frauenberg, Niederbayern. Geoarchaeology 18(7):757-778. http://dx.doi.org/10.1002/gea.10088

Larson, G., U. Albarella, K. Dobney, P. Rowley-Conwy, J. Schibler, A. Tresset, J.-D. Vigne, C. J. Edwards, A. Schlumbaum, a. Dinu, et al. 2007. Ancient DNA, pig domestication, and the spread of the Neolithic into Europe. Proceedings of the National Academy of Sciences of the United States of America 104 (39):15276-15281. http://dx.doi.org/10.1073/pnas.0703411104

Lemmen, C., D. Gronenborn, and K. W. Wirtz. 2011. A simulation of the Neolithic transition in Western Eurasia. Journal of Archaeological Science 38(12):3459-3470. http://dx.doi. org/10.1016/j.jas.2011.08.008

Leopold, M., T. Plöckl, G. Forstenaicher, and J. Völkel. 2010. Integrating pedological and geophysical methods to enhance the informative value of an archaeological prospection - the example of a Roman villa rustica near Regensburg, Germany. Journal of Archaeological Science 37(7):1731-1741. http://dx.doi.org/10.1016/ j.jas.2010.01.033

Leopold, M., and J. Völkel. 2007. Colluvium: definition, differentiation, and possible suitability for reconstructing Holocene climate data. Quaternary International 162-163:133140. http://dx.doi.org/10.1016/j.quaint.2006.10.030 
Levitt, T. 1999. The globalization of markets. Pages 249-266 in R. Z. Aliber and R. W. Click, editors. Readings in international business: a decision approach. Third printing. MIT Press, Cambridge, Massachusetts, London, UK.

Liebig, J. 1841. Die organische Chemie in ihrer Anwendung auf Agricultur und Physiologie. Verlag von Friedrich Vieweg und Sohn, Braunschweig.

Linke, M. 1979. Zur Verbreitung, Form und Entstehung altmärkischer Wölbäcker. Hercynia N. F. 16(4):431-439.

Lüning, J. 2000. Steinzeitliche Bauern in Deutschland - die Landwirtschaft im Neolithikum. Verlag Dr. Rudolf Habelt GmbH, Bonn.

Luterbacher, J., D. Dietrich, E. Xoplaki, M. Grosjean, and H. Wanner. 2004. European seasonal and annual temperature variability, trends, and extremes since 1500. Science 303:14991503. http://dx.doi.org/10.1126/science.1093877

MacDonald, G. K., E. M. Bennett, P. A. Potter, and N. Ramankutty. 2011. Agronomic phosphorus imbalances across the world's croplands. Proceedings of the National Academy of Sciences 108(7):3086-3091. http://dx.doi.org/10.1073/pnas.1010808108

Mäckel, R., R. Schneider, and J. Seidel. 2003. Anthropogenic impact on the landscape of southern Badenia (Germany) during the Holocene - documented by colluvial and alluvial sediments. Archaeometry 45(3):487-501. http://dx.doi.org/10.1111/1475-4754.00123

McNeill, J. R., and V. Winiwarter. 2004. Breaking the sod: humankind, history, and soil. Science 304(5677):1627-1629. http://dx.doi.org/10.1126/science.1099893

Mellars, P. 2004. Neanderthals and the modern human colonization of Europe. Nature 432:461-465. http://dx.doi. org/10.1038/nature03103

Mitusov, A. V., O. E. Mitusova, J. Wendt, S. Dreibrodt, and H.R. Bork. 2014. Correlation of colluvial deposits with the modern land surface and the problem of slope profile description. Geomorphology 220:30-40. http://dx.doi.org/10.1016/j.

geomorph.2014.05.020

Montgomery, D. R. 2010. Dreck: Warum unsere Zivilisation den Boden unter den Füßen verliert. oekom verlag, München.

Mueller, K. 2015. Der Spaten - ein Bodenbearbeitungsgerät im Wandel der Zeit. Pages 199-208 in H.-P. Blume and R. Horn, editors. Persönlichkeiten der Bodenkunde V: Beiträge zum 350. Jubiläum der Christian-Albrechts- Universität zu Kiel. Vorträge der Arbeitsgruppe Geschichte der Bodenkunde im Rahmen der Jahrestagung der Deutschen Bodenkundlichen Gesellschaft im September 2013 in Rostock. R. Horn und K. H. Mühling.

Niedertscheider, M., T. Kuemmerle, D. Müller, and K.-H. Erb. 2014. Exploring the effects of drastic institutional and socioeconomic changes on land system dynamics in Germany between 1883 and 2007. Global Environmental Change 28:98-108. http:// dx.doi.org/10.1016/j.gloenvcha.2014.06.006

Nüsse, H.-J., C. Marx, and D. Lelgemann. 2011. Germania magna - Ein neuer Blick auf eine alte Karte: Entzerrte geographische Daten des Ptolemaios für die antiken Orte zwischen Rhein und Weichsel. Germania 89(1-2):115-153.
Pape, J. C. 1970. Plaggen soils in the Netherlands. Geoderma 4 (3):229-255. http://dx.doi.org/10.1016/0016-7061(70)90005-4

Pietsch, D., and P. Kühn. 2014. Buried soils in the context of geoarchaeological research - two examples from Germany and Ethiopia. Archaeological and Anthropological Sciences. http://dx. doi.org/10.1007/s12520-014-0180-9

Pimentel, D., and N. Kounang. 1998. Ecology of soil erosion in ecosystems. Ecosystems 1(5):416-426. http://dx.doi.org/10.1007/ $\underline{\mathrm{s} 100219900035}$

Pinhasi, R., M. G. Thomas, M. Hofreiter, M. Currat, and J. Burger. 2012. The genetic history of Europeans. Trends in Genetics 28(10):496-505. http://dx.doi.org/10.1016/j.tig.2012.06.006

Price, T. D., R. A. Bentley, J. Lüning, D. Gronenborn, and J. Wahl. 2001. Prehistoric human migration in the Linearbandkeramik of Central Europe. Antiquity 75(289):593-603. http://dx.doi. org/10.1017/S0003598X00088827

Prummel, W., and M. J. Niekus. 2011. Late Mesolithic hunting of a small female aurochs in the valley of the River Tjonger (the Netherlands) in the light of Mesolithic aurochs hunting in NW Europe. Journal of Archaeological Science 38(7):1456-1467. http://dx.doi.org/10.1016/j.jas.2011.02.009

Rebourg, C., M. Chastanet, B. Gouesnard, C. Welcker, P. Dubreuil, and A. Charcosset. 2003. Maize introduction into Europe: the history reviewed in the light of molecular data. Theoretical and Applied Genetics. Theoretische und angewandte Genetik 106(5):895-903. http://dx.doi.org/10.1007/s00122-002-1140-9

Reiß, S., S. Dreibrodt, C. C. M. Lubos, and H.-R. Bork. 2009. Land use history and historical soil erosion at Albersdorf (northern Germany) - ceased agricultural land use after the prehistorical period. Catena 77(2):107-118. http://dx.doi.org/10.1016/ j.catena.2008.11.001

Robertson, R. 1992. Globalization: social theory and global culture. SAGE Publications, London, UK. http://dx.doi. org/10.4135/9781446280447

Rösch, M. 1987. Der Mensch als landschaftsprägender Faktor des westlichen Bodenseegebietes seit dem späten Atlantikum. Eiszeitalter und Gegenwart 37:19-29.

Rösch, M. 1993. Prehistoric land use as recorded in a lake-shore core at Lake Constance. Vegetation History and Archaeobotany 2:213-232.

Rösch, M. 1996. New approaches to prehistoric land-use reconstruction in south-western Germany. Vegetation History and Archaeobotany 5:65-79. http://dx.doi.org/10.1007/BF00189436

Rösch, M. 1998. The history of crops and crop weeds in southwestern Germany from the Neolithic period to modern times, as shown by archaeobotanical evidence. Vegetation History and Archaeobotany 7:109-125. http://dx.doi.org/10.1007/BF01373928

Rösch, M. 2009. Vom Korn der frühen Jahre: Sieben Jahrtausende Ackerbau und Kulturlanschaft. Denkmalpflege in BadenWürttemberg. Nachrichtenblatt des Landesdenkmalamtes 38 (3):157-164.

Rösch, M., O. Ehrmann, L. Herrmann, E. Schulz, A. Bogenrieder, J. P. Goldammer, M. Hall, H. Page, and W. Schier. 2002. An 
experimental approach to Neolithic shifting cultivation. Vegetation History and Archaeobotany 11:143-154. http://dx.doi. org/10.1007/s003340200016

Rösch, M., S. Jacomet, and S. Karg. 1992. The history of cereals in the region of the former Duchy of Swabia (Herzogtum Schwaben) from the Roman to the Post-medieval period: results of archaeobotanical research. Vegetation History and Archaeobotany 1:193-231. http://dx.doi.org/10.1007/BF00189499

Rösch, M., and G. Tserendorj. 2011. Florengeschichtliche Beobachtungen im Nordschwarzwald (Südwestdeutschland). Hercynia N. F. 44:53-71.

Sanden, W. v. d. 1994. Early Iron Age ard shares from Drenthe, the Netherlands. Tools \& Tillage 7(2):103-106.

Schmitt, A., M. Dotterweich, G. Schmidtchen, and H.-R. Bork. 2003. Vineyards, hopgardens and recent afforestation: effects of late Holocene land use change on soil erosion in northern Bavaria, Germany. Catena 51:241-254. http://dx.doi.org/10.1016/S0341-8162 (02)00171-6

Schneider, H. 2007. Geschichte der antiken Technik. C.H. Beck oHG, München. http://dx.doi.org/10.17104/9783406692857

Scholten, T. 2014. Mensch und Boden. Praxis Geographie(1):4-7.

Schultz-Klinken, K.-R. 1981. Haken, Pflug und Ackerbau: Ackerbausysteme des Saatfurch- und Saatbettbaues in urgeschichtlicher und geschichtlicher Zeit sowie ihr Einfluß auf die Bodenentwicklung. August Lax Verlagsbuchhandlung, Hildesheim.

Schumacher, E. F. 1993. Small is beautiful: a study of economics as if people mattered. Vintage Books, London, UK.

Seidl, A. 2006. Deutsche Agrargeschichte. DLG-Verlags-GmbH, Frankfurt am Main.

Shen, J., R. Li, F. Zhang, J. Fan, C. Tang, and Z. Rengel. 2004. Crop yields, soil fertility and phosphorus fractions in response to long-term fertilization under the rice monoculture system on a calcareous soil. Field Crops Research 86(2-3):225-238. http://dx. doi.org/10.1016/i.fcr.2003.08.013

Smil, V. 1999. Nitrogen in crop production: an account of global flows. Global Biogeochemical Cycles 13(2):647-662. http://dx.doi. org/10.1029/1999GB900015

Smil, V. 2000. Phosphorus in the environment: natural flows and human interferences. Annual Review of Energy and the Environment 25:53-88. http://dx.doi.org/10.1146/annurev.energy.25.1.53

Spek, T., W. Groenman-van Waateringe, M. Kooistra, and L. Bakker. 2003. Formation and land-use history of Celtic fields in north-west Europe - an interdisciplinary case study at Zeijen, The Netherlands. European Journal of Archaeology 6(2):141-173. http://dx.doi.org/10.1179/eja.2003.6.2.141

Statistisches Bundesamt. 2016. Produktionsmethoden:

Bodenbearbeitungsverfahren landwirtschaftlicher Betriebe auf Ackerflächen im Wirtschaftsjahr 2009/2010. [online] URL: https://www.destatis.de/DE/ZahlenFakten/Wirtschaftsbereiche/ LandForstwirtschaftFischerei/Produktionsmethoden/Tabellen/ BodenbearbeitungsverfahrenLB.html
Steuer, H. 1993. Von der Steinzeit bis zum Mittelalter Erzgewinnung als Spiegel der Epochen. Pages 7-15 in H. Steuer and U. Zimmermann, editors. Alter Bergbau in Deutschland. Konrad Theiss Verlag, Stuttgart, Germany.

Stika, H.-P., and A. G. Heiss. 2013. Plant cultivation in the Bronze Age. In H. Fokkens, and A. Harding, editors. The Oxford handbook of the European Bronze Age. Oxford University Press, Oxford, UK.

Stockmann, U., B. Minasny, and A. B. McBratney. 2014. How fast does soil grow? Geoderma 216:48-61. http://dx.doi. org/10.1016/j.geoderma.2013.10.007

Tegtmeier, U. 1993. Neolithische und bronzezeitliche Pflugspuren in Norddeutschland und den Niederlanden. Magisterarbeit, Bonn.

Teixeira, E. I., P. Johnstone, E. Chakwizira, J. D. Ruiter, B. Malcolm, N. Shaw, R. Zyskowski, E. Khaembah, J. Sharp, E. Meenken, P. Fraser, S. Thomas, H. Brown, and D. Curtin. 2016. Sources of variability in the effectiveness of winter cover crops for mitigating $\mathrm{N}$ leaching. Agriculture, Ecosystems \& Environment 220:226-235. http://dx.doi.org/10.1016/j.agee.2016.01.019

Terberger, T., P. de Klerk, H. Helbig, K. Kaiser, and P. Kühn. 2004. Late Weichselian landscape development and human settlement in Mecklenburg-Vorpommern (NE Germany). Eiszeitalter und Gegenwart 54:138-175.

Thaer, A. D. 1880. Albrecht Thaer's Grundsätze der rationellen Landwirthschaft. Wiegandt, Hempel \& Parey, Berlin, Germany.

Tiedje, J. M., R. K. Colwell, Y. L. Grossman, R. E. Hodson, R. E. Lenski, R. N. Mack, and P. J. Regal. 1989. The planned introduction of genetically engineered organisms: ecological considerations and recommendations. Ecology 70(2):298-315. http://dx.doi.org/10.2307/1937535

Tilman, D., K. G. Cassman, P. A. Matson, R. L. Naylor, and S. Polasky. 2002. Agricultural sustainability and intensive production practices. Nature 418:671-677. http://dx.doi. org/10.1038/nature01014

Tinner, W., and A. F. Lotter. 2001. Central European vegetation response to abrupt climate change at $8.2 \mathrm{ka}$. Geology 29(6):551554.

Tolksdorf, J. F., K. Kaiser, S. Veil, N. Klasen, and H. Brückner. 2009. The Early Mesolithic Haverbeck site, Northwest Germany: evidence for Preboreal settlement in the Western and Central European Plain. Journal of Archaeological Science 36(7):14661476. http://dx.doi.org/10.1016/j.jas.2009.03.002

Tresset, A., and J.-D. Vigne. 2011. Last hunter-gatherers and first farmers of Europe. Comptes rendus biologies 334(3):182-189. http://dx.doi.org/10.1016/j.crvi.2010.12.010

Uekoetter, F. 2012. Die Wahrheit ist auf dem Feld: Eine Wissensgeschichte der deutschen Landwirtschaft. Vandenhoeck \& Ruprecht GmbH, Göttingen.

Uerpmann, H.-P. 2007. Von Wildbeutern zu Ackerbauern: Die Neolithische Revolution der menschlichen Subsistenz. Mitteilungen der Gesellschaft für Urgeschichte 16:55-74. 
van Beek, R., and B. Groenewoudt. 2011. An Odyssey along the River Vecht in the Dutch-German border area: a region analysis of Roman-period sites in Germania Magna. Germania 89(1-2).

van Mourik, J. M., A. C. Seijmonsbergen, R. T. Slotboom, and J. Wallinga. 2012. Impact of human land use on soils and landforms in cultural landscapes on aeolian sandy substrates (Maashorst, SE-Netherlands). Quaternary International 265:7489. http://dx.doi.org/10.1016/j.quaint.2011.06.053

Verheijen, F., R. Jones, R. J. Rickson, and C. J. Smith. 2009. Tolerable versus actual soil erosion rates in Europe. Earth-Science Reviews 94(1-4):23-38. http://dx.doi.org/10.1016/j.earscirev.2009.02.003

West, P. C., H. K. Gibbs, C. Monfreda, J. Wagner, C. C. Barford, S. R. Carpenter, and J. A. Foley. 2010. Trading carbon for food: global comparison of carbon stocks vs. crop yields on agricultural land. Proceedings of the National Academy of Sciences of the United States of America 107(46):19645-19648. http://dx.doi. org/10.1073/pnas.1011078107

Whitehouse, N. J., and W. Kirleis. 2014. The world reshaped: practices and impacts of early agrarian societies. Journal of Archaeological Science 51:1-11. http://dx.doi.org/10.1016/j. jas.2014.08.007

Wieckowska, M., W. Dörfler, and W. Kirleis. 2012. Vegetation and settlement history of the past 9000 years as recorded by lake deposits from Großer Eutiner See (Northern Germany). Review of Palaeobotany and Palynology 174:79-90.

Wilson, R. J. A. 2006. What's new in Roman Baden-Württemberg? Journal of Roman Studies 96:198-212.

Winiwarter, V. 2006. Prolegomena to a history of soil knowledge in Europe. Pages 177-215 in J. R. McNeill and V. Winiwarter, editors. Soils and societies: perspectives from environmental history. Second edition. White Horse Press, Isle of Harris, UK.

Zich, B. 1999. Das Hügelgräberfeld von Flintbek nach zwanzig Ausgrabungsjahren. Jahrbuch für das ehemalige Amt Bordesholm $1: 1-52$.

Zimmermann, A. 2012. Cultural cycles in Central Europe during the Holocene. Quaternary International 274:251-258. http://dx. doi.org/10.1016/j.quaint.2012.05.014

Zolitschka, B., K.-E. Behre, and J. Schneider. 2003. Human and climatic impact on the environment as derived from colluvial, fluvial and lacustrine archives-examples from the Bronze Age to the Migration period, Germany. Quaternary Science Reviews 22 (1):81-100. http://dx.doi.org/10.1016/S0277-3791(02)00182-8

Zvelebil, M., M. C. Lillie, J. Montgomery, A. Lukes, P. Pettitt, and M. P. Richards. 2012. The emergence of the LBK: migration, memory and meaning at the transition to agriculture. Pages 133148 in E. Kaiser, J. Burger, and W. Schier, editors. Population dynamics in prehistory and early history: new approaches by using stable isotopes and genetics. de Gruyter, Berlin, Germany. http:// dx.doi.org/10.1515/9783110266306.133 